\title{
Smoke with Fire: Financial Crises, Institutional Reform, and the Future of EU Democracy
}

\author{
Federica Genovese* Gerald Schneider ${ }^{\dagger}$
}

September 14, 2014

The handling of the recent sovereign debt crisis in Europe has raised fears that decision making among European countries has become less democratic, and that technocrats now call the shots in the European Union (EU). In this article we confront this view by proposing an alternative theory for the effects of financial crises in this supranational organization. We argue that national parliaments in Europe refrain from demanding control of EU institutions during a financial crisis if they think their request may undermine the credibility of governments in other member states their policies depend on. A crisis should then depress demand for political reforms in monetarily independent countries that are in financial trouble, but not in countries whose fiscal and monetary status rely on the economic reputation of the Union as a whole. We show evidence in support of our theory with qualitative evaluations and econometric regressions, using different types of data for the years between 1950 and 2010. Our findings let us reconsider that the recent Eurocrisis has depleted the power of the European legislatures.

*Stanford University; genovese.federica@gmail.com

${ }^{\dagger}$ University of Konstanz; gerald.schneider@uni-konstanz.de. Previous versions of this paper have been presented at the meeting of the 2012 German Political Science Association (DVWP) at the University of Tübingen and at research seminars at the Free University Berlin, Leiden University, WZB, Tel Aviv University and the Institute for Advance Studies Toulouse. We thank the participants and Zareh Asatryan, Simon Hix, Martin Höppner, Kai Konrad, Rhea Molato, John Roemer, Thomas Sattler, Tal Sadeh, Enrico Spolaore, Aneta Spendzharova, Bernard Steunenberg, Jean Tirole and Vera Tröger for constructive comments. We are also grateful to Alexander Bräunig for research assistance and Cristina Bodea, Tal Sadeh and Thomas Winzen for sharing data. Replication data and files will be found at the homepage of the first author. 
"There's no smoke without fire, Baby, baby you're a liar"

- Duffy, Smoke with Fire

The political economy literature disagrees over the conditions under which a country introduces political reforms following a severe economic shock. A main proposition within this body of research boils down to the expectation that governments do not launch policy reforms without the pressure from crises. Rodrik (1996: 27) pointed out that this thesis borders on tautology, arguing, "[t]hat policy reform should follow crises, then, is no more surprising than smoke following fire." Others have, however, uncovered the considerable delay in which many countries implement urgent policies (Alesina and Drazen 1991), invoking at least for a certain period of time the possibility of 'smoke-free fire' and thus crises that do not lead to any real reforms. Indeed, at the beginning of the recent European sovereign debt crisis Greek decision makers provoked several wars of nerves until they reluctantly accepted some of the austerity measures designed by the European Union (EU) and the International Monetary Fund.

The fact that Greece and other EU member governments have deferred deadlines and postponed decisions on key austerity measures has reinvigorated the fear that the Union has reached its nadir, having fallen victim to a final bout of what Giersch (1985) had described as 'Eurosclerosis.' The post-2008 political inertia was supposedly dictated by a few governments, which prevented the organization from introducing reforms that would enable it to effectively deal with crises. For some, the end of integration seemed closer than ever before in the history of the 'EU project.' The renewed debate over the alleged democratic deficit in Europe accompanied the pessimistic view that supranational organizations are unable to confront economic challenges successfully. Intellectuals and social exponents have complained that the handling of the crisis undermined European democracy, identifying a trend towards technocratic and even autocratic decision making. ${ }^{1}$

\footnotetext{
${ }^{1}$ In 2012 prominent sociologist Anthony Giddens noted, "what about the fate of democracy in all this? Those who have assumed the mantle of the saviors of the EU - Angela Merkel and Nicolas Sarkozy, together with 'technocrats' in Greece and Italy - are largely bypassing the decision-making agencies of the union"
} 
Addressing the question whether 'smoke follows fires' in light of these concerns, this paper examines the institutional consequences of financial collapses in Europe. We present an argument that links together lessons from the literature on the effects of crises on policy, coalition building and unanimity voting, seeking to explain the trajectory of supranational decision making in the continent from the post-war years until today. On the one hand, remarkable integration and progressive legalization have occurred in the aftermath of crises in modern Europe. This observation leads us to believe the EU is a supra-nationalist democracy with the capacity to introduce institutional changes that are more universally beneficial than the status quo in the wake of a financial crisis. On the other hand, the organization gathers states with heterogeneous sensitivities to economic and political change. Do these diverging preferences challenge democratic reforms? We will argue that the majority of EU states do not demand reforms at the outbreak of crises, because they fear the political costs resented in weaker countries upon which the Union depends. So, even if countries have domestic incentives to request more reforms of the EU, they may not pursue them at the time of a crisis in order not to shame the political and economic credibility of the Union.

We identify two dimensions where we think the main institutional reforms in Europe should be foreseen. A first dimension regards the degree to which governments are enabled to delegate decision making power to autonomous economic agencies. Central banks are key agents, because they are in charge of maintaining public confidence in trade, savings and investment in weakened payments system (Kapstein 1992; Bernhard et al 2002). The second dimension deals with the extent to which the national parliaments are able to restrain executive decision-making and rebalance political rights (Finke 2009; Saalfeld 2005). While these two types of reform share the goal of protecting legislatures and curtailing executives' discretion, they are at loggerheads with each other, as empowering independent economic agents like the central bank lowers the control possibilities of the legislative actors, and vice versa. In the EU the trade-off is made more difficult by the two legislative levels, and the fact

(Giddens 2012). Fearing the "real possibility of a failure of the European project," Jürgen Habermas (2011: 97) advanced the proposal of establishing a European transnational democracy. 
that the supranational parliament can constrain the degree of political scrutiny of national legislatures on Brussels. We contend that financial crises in the EU allow national systems with monetary independence to demands for more political scrutiny and direct oversight institutions unless a crisis breaks out. Oppositely, we claim that more bounded countries, such as the members of the European Monetary Union (EMU), face fewer collective incentives to press for political shifts, because they share a common credibility in the time of a crisis.

We test our theory leveraging political and economic data between 1950 and 2010 . In line with our expectation, our empirical evidence indicates that historical crises have empowered economic agents like national central banks, including the banks of monetarily independent countries in 2008-10. However, more integrated states show no significant differences in demand for political reforms whether they suffered from a crisis or not. The results are compelling and have important implications for democracy and delegation in the continent after the recent Eurocrisis. We conclude by discussing the implications of the distributional concerns over policy participation for the future of monetary integration and political governance in the EU.

\section{Financial Crises and Institutional Reforms}

\section{The New Debate on the Democratic Deficit}

One of the key features in the history of the European Union is the stop-and-go nature in which the organization has institutionally evolved over time (Schneider and Cederman 1994). Observers have frequently described the periods in which attempts to widen and deepen the process of European integration failed as crises that might herald the end of the integration process altogether. The inability of the European Council - and thus the intergovernmental forum of the Heads of States and Prime Ministers - to deal with the 2008 sovereign debt crisis in a timely and effective manner has reinvigorated such concerns. Several European leaders took up the doomsday rhetoric of earlier periods of stagnation and tried to convince their 
electorates that a failure to resolve the debt crisis would result in an irreparable breakdown of the European institutions and the escalation towards a situation in which the specter of a European war would loom large.

While some saw such developments as a welcome chance to reduce the integration project to the alleged core function of a free-trade area, leading European intellectuals rather believed that more formalized cooperation is needed to tackle the problems of the integration process. Habermas (2011) vigorously voiced the latter position, complaining that one institutional consequence of the crises, the strengthening of 'executive federalism,' has led to an intergovernmentalist hollowing out of democracy in Europe. This endangers, in his view, the ambition to establish transnational cosmopolitanism through the integration project. Streeck (2011, 2013), by contrast, believes that the interests of the financial industry will prevent the organization from becoming more democratic. In his view, "[m]ore than ever, economic power seems today to have become political power, while citizens appear to be almost entirely stripped of their democratic defences and their capacity to impress upon the political economy interests and demands that are incommensurable with those of capital owners" (Streeck 2011: 29).

The claim that the financial crises within the EU have undermined the legitimacy of decision making in the supranational institution has re-launched the discussion over the socalled 'democratic deficit' and the measures that could be taken to resolve it. ${ }^{2}$ Although we do not want to rehash here the rich discussion over this continuing challenge, a key disagreement is worth identifying. On the most controversial end, Moravcsik (2002) and Majone $(1996,1998)$ contend that there is no real deficit as the ambition of the integration project is a more technocratic one. The EU, in other words, is a highly efficient bureaucratic machine that produces efficient technical solutions in less politicized arenas. A lack of democracy is, therefore, not really a problem for the organization. Føllesdal and Hix (2006), by contrast,

\footnotetext{
${ }^{2}$ In a review of Streeck (2013), Habermas (2013) deplores the alleged wish to return to the nation-state 'corral' of the 1960s and 1970s. His insistence on an EU solution has inspired a plethora of projects, including the "Manifesto for re-building Europe from the bottom-up" which called for "a European Year of Volunteering for Everyone" (http://manifest-europa.eu/?lang=en,13/9/2012). Accessed on 26 April 2014.
} 
contend that the decision making power of the European Union reach far beyond a level where only technocratic expertise is required and that decisions over these issues are done by government delegates who cannot base their position on a clear popular mandate. Hix (2008) has therefore called for a strengthening of democracy in the EU through open contestation for public offices, more transparent decision making in the Commission and a move away from consensus in parliamentary agenda setting.

These different positions are hardly reconcilable as they are based on diverging understandings of whether decisions by independent technocrats or by democratically legitimized actors dominate day-to-day affairs in the supranational organization. Nonetheless, we agree with Hix (2008) that decisions of the organization have severe redistributive consequences that require democratic control and transparency. One can obviously maintain that some of the ideas advanced in the discussion on the democratic deficit - like the creation of a European public sphere or the introduction of EU-wide referenda - would be appropriate means to legitimize EU decision making. However, the realization of such projects is not imminent so that we need to examine how decisions on financial crises are made and whether there is room to increase the legitimacy and efficiency of these choices.

\section{The Consequences of Crises in a Supranational Polity}

Our entity of interest is a supranational union that shares few similarities with other types of political organizations. And yet, despite the fact that the political ramifications of crises in Europe go beyond the borders of a single country, some aspects of the constitutional dilemma in the aftermath of economic shocks are comparable to the consequences in other polities. One general claim in the literature is that economic shocks are a key driver of political liberalization. This view is supported by careful studies of cross-national transitions. ${ }^{3}$

\footnotetext{
${ }^{3}$ For example, Ulfelder (2009) notes that "poor economic growth produces declines in living standards that spurred popular rebellion. Threatened by these uprisings and often hobbled by an accompanying fiscal crisis that also undermined the loyalty of key elites, dictators sometimes respond with political liberalization" (Ulfelder 2009: 28). Similarly, Acharya (1999, 432) suggests "that economic downturns can precipitate the breakdown of authoritarian rule" based a survey of south Asian countries after the economic crisis of the late 1990s.
} 
There is also evidence that countries increase the discretion of their central monetary agencies in the wake of financial crises. An encompassing empirical study by Crowe and Meade (2008: 766) suggests that past inflationary experience increases central bank independence, suggesting that "reform has been prompted by the failure of past anti-inflation." A further important determinant of this form of institutional change is political stress, which in itself might be spurred by economic crises. While inflation negatively affects the risk of growing central bank independence, an index of political instability is positively associated with it (Polillo and Guillén 2005). ${ }^{4}$ Bernhard (2002) furthermore shows that governments which have to fear to be punished for a mismanagement of the economy have an increased tendency to delegate more power to central banks.

These crisis arguments are at loggerheads with the modernization literature which links the prospects of democratization to economic development. ${ }^{5}$ Evidently, we should not expect financial crises to always result in institutional reform. Policy transitions can be slow, stalled or even blackmailed as most reforms inevitably pose the question of which group should shoulder the costs of the adaptation (Alesina and Drazen 1991). However, the social costs of a crisis can sometimes be so overpowering that they enable rather than prevent drastic policy reforms. ${ }^{6}$ Several empirical studies support this optimistic expectation. For example, Frankel (2005) shows for developing countries that the risk that a central banker is held accountable (losing her job) after a currency crisis is over 60 per cent higher in

\footnotetext{
${ }^{4}$ The negative impact of inflation on central bank independence could be a consequence of a simultaneity problem. Hielscher and Markwardt (2012) for instance demonstrate that only significant steps towards further independence lower inflation and that the leeway granted to the central banks reforms has to be embedded into a political system with high quality institutions to make the reforms effective.

${ }^{5}$ Recent tests of this thesis, originally advanced by Lipset (1959), have led to inconclusive results (Prezeworski and Limongi 1997, Prezeworski et al. 2000, Epstein et al. 2006, Acemoglu et al. 2008). Kennedy (2010: 785) bluntly notes that "[e]conomic development generally increases the stability of authoritarian regimes."

${ }^{6}$ Along these lines, Drazen and Grilli (1993: 598) claim that major economic distortions can be 'beneficial' and may induce necessary economic reforms: "the extreme welfare loss that each agent suffers in a crisis dwarfs the loss he may associate with an unfavorable distribution of the burden of a major policy change." Note however that this conjecture is in considerable contrast with some historical work that traces the authoritarian transitions of the 1930s to the Great Depression (e.g. Kindleberger 1986). More recent comparative studies demonstrate that not only economic factors contributed to the rise of fascism in the Western Europe of the early 1930s (e.g. de Bromhead et al. 2013).
} 
that year in comparison to a less turbulent year. Of course, firing the underlings does not completely banish the danger for a government leader to be forced out of office. ${ }^{7}$ Sacking the allegedly responsible policy makers is nevertheless a short-term response to an economic crisis. A more long-term response would consist of institutional changes that reduce the risk of future financial crises. On this end, some research has indicated that economic crises in liberalized countries go hand in hand with more political accountability and governmental transparency..$^{8}$

While the comparative scholarship lends important lessons to our understanding of the relation between crises, policy and democracy across countries, we recognize that some of these assumptions do not necessarily have to hold in the context of the EU. The European Union is still a predominantly intergovernmental institution that decides on reactions to fiscal crises through negotiations between the heads of government and largely independent agencies such as the European Central Bank (ECB). Consequently, our discussion of the institutional consequences of financial crises in the EU needs to focus on the interrelated questions of how much parliamentary scrutiny the intergovernmental decision making should receive and how independent the central bank shall be. These two questions have been separately raised in recent comparative EU literature. ${ }^{9}$ Here we link them in order to construct theoretical expectations on the trade-offs between economic reforms and political accountability in the EU after a financial crisis.

\footnotetext{
${ }^{7}$ According to Frankel's calculation, this risk is more than 30 percent higher following the devaluation in the preceding year compared to a normal year.

${ }^{8}$ The countries where crises are more strongly correlated with democratization are those with sizeable investment flows and high stability goals, in other words states that are both committed to integration in the international banking system and domestic stability (Bordo and Schwartz 1997).

${ }^{9}$ See, for example, Moravcsik (2012) on the politics of EU banking, and Winzen (2013) and de Wilde (2014) on the attitudes of national parliaments towards the EU institutional process.
} 


\section{How do Crises affect Institutions in the EU?}

We generally expect that citizens who suffer from the negative effects of financial turmoil will try to punish their leaders for the hardship they have to endure. ${ }^{10}$ However, citizens should not automatically punish leaders for economic hardship if the causes of the crisis are blurry, as it has often been the case since the end of the world wars. Without being able to directly account for the originator of the economic troubles, the electoral consequences of severe austerity measures in developed democracies may be overall small (Alesina et al. 2011). We think this holds true at the level of the EU, where supranational elections are still far from being an equivalent delegation process like their national counterparts. ${ }^{11}$ Therefore, we believe there are indirect mechanisms through which politicians can pull the strings of EU institutions, although at some conditions that we address in what follows.

We identify two alternative chances for reform at the onset of a crisis. On one front, in the aftermath of a crisis citizens should ask for institutional reforms that limit the costs of governmental policies, constrain the role of governments in the economy, and improve the position of technocratic actors such as the central bankers. The second option is demanding more legislative control and more direct delegation. We now discuss the incentives that come with each of the two options, and how crises may influence the set of preferences for these two types of reforms.

\footnotetext{
${ }^{10}$ The literature provides compelling evidence in support of this expectation. Bueno de Mesquita et al. (2003) provide solid evidence that leaders who have not been economically successful face a higher chance of being outvoted or overthrown. Similarly, Smith (2008: 792) argues that democratization helps pressurized leaders to find a compromise between the competing demands of the supporting political elite and the citizens as "increases in coalition size shift the policy focus of the winning coalition closer to the policy goals of those outside of the coalition." Moreover, Stasavage (2011) shows that the development of public credit tends to accompany the development of representative institutions.

${ }^{11}$ The average turnout in national elections in the funding European countries is more than 15 percent higher than the turnout of the past EU Parliament elections, according to EurActiv, 2014, http://www.euractiv.com/sections/eu-elections-2014/ slightly-higher-election-turnout-averted-big-disaster-302383.
} 


\section{Effect of Crises on Economic Reforms: Central Banking}

The international politics of central banks are bound to the 'trilemma in history' (Obstfeld et al. 2004), in which the autonomous monetary policy of central banks negates either the choice of a fixed exchange rate or the benefits of free international capital mobility. Various macroeconomic decisions traceable to this trilemma featured across Europe before the establishment of the European Monetary Union (EMU). In a Special Issue of International Organization, Frieden (2002) shows that domestic arrangements determined variation of currency policies in European countries before the Maastricht Treaty, especially when more independent agencies decreased the need for anti-inflationary credibility associated with pegged currencies. In the same Special Issue, Bernhard et al (2002) note that "[d]elegation to a conservative central bank forces a trade-off between lower inflation and output stabilization: the more conservative the central banker, the less she stabilizes output in the face of unanticipated disturbances, especially under supply shocks" (p. 14).

We second this theory that increasing the agency of central bankers allows countries to maintain international credibility, especially when assets must be liquidated quickly in the aftermath of a crisis. Following Broz (2002), we also believe that democracies in particular use changes to central bank independence (CBI) to maintain their cross-national investments, because their banks are overall more credible than the ones in autocracies. Given the strong movements towards democratization in the modern history of the EU member countries, we expect European governments to have a high propensity to increase financial transparency in the aftermath of a crisis. This transparency is equivalent to delegating economic decisions to autonomous central bankers.

While we argue that this mechanism should hold for independent European countries, we believe it may not be in place for countries that entered the EMU starting in 1993, after the Maastricht Treaty. As a condition for joining the common currency, the Treaty imposed significant strengthening of the independence of central banks. This proposal followed the logic that the principal benefit of fixing European exchange rates was facilitation 
of cross-border trade within the EU. Hence, it was necessary that countries agreed to the loss of ability to use currency policy. Obviously the negotiations of the EMU Treaty were characterized by different views. Countries with harder currencies like Germany debated the importance for contained inflation and low interest rates. By contrast, in countries with weaker currencies politicians saw monetary union as a means to commit themselves to credible cross-border investment and an 'optimal currency.' But as Moravskic (2012) points out, a reason for monetary integration was precisely a strong concern for economic instability in Europe in the 1970s. Spain and Italy, among others, embraced the combination of CBI and free capital flow at the cost of flexible monetary policies at a time when currency and debt crises were threatening their trade. Ultimately the Maastricht Treaty 'artificially' reduced the variation of central bank independence in EMU countries. Consequently, all EMU countries had no more domestic freedom to set the level of independence of central banks, not even at the time of the 2008 crisis.

Hypothesis 1: Financial crises have increased CBI in European countries after the war, but had no effect on CBI in EMU countries after the Maastricht Treaty.

From the above discussion it follows that, under the Maastricht framework, a country faced with a spillover crisis would have to act by pushing down economic activity through scarce resources. The decision to trade off fixed CBI levels with tight policies was natural to Germany, where the delegation of power to the central bank had been solidified since 1958. However, it was a challenge for other European governments. Delegation of powers to the CB does not enhance credibility if it can be easily reverted, since in this case delegation itself is subject to credibility problems. So, if changing the level of independence of the central bank is difficult, then governments can only influence economic decisions with other instruments. One such instrument is fiscal policy.

European countries had very different types of debts coming out of World War II, and our focus here will not be on specific mechanisms due to debt levels. However, fiscal spending has usually played a relevant role in the story of economic reforms. Expenditure allowed 
most governments in the run-up to the Euro to reach growth goals necessary for further integration. The Maastricht convergence criteria, for example, allowed 'moderate' levels of debt (up to 60 percent of GDP) in order to balance the future monetary policy constraints. ${ }^{12}$ This said, we expect the differences in fiscal policies to be inconclusive in explaining the level of CBI among EMU countries in the aftermath of crises, because the monetary reforms in the Eurozone after 1993 were bound to rigorous, anticipated criteria. In other words, we know that since the creation of the European Central Bank (ECB) in 1999 neither the more indebted nor the more 'fiscally sober' EMU candidates proposed (or enacted) changes to CBI (Alesina and Drazen 1991).

Less clear is the impact of debt at the time of a crisis among monetarily independent EU countries. Governments with fiscal leeway could use less fiscal pressure or, alternatively, more spending to incentivize domestic investments and movement of capital. According to the standard Mundell-Fleming model, increased government expenditure in a small open economy can be combined with expanding monetary authority in order to increase the general income of the economy without affecting interest rates. However, fiscal policy is only effective in a fixed exchange rate regime. Given the higher heterogeneity of non-EMU countries and the different degrees of spillover that crises in a European country can have on the other, one could expect a slow implementation of fiscal policy to have an insignificant impact on reforms towards economic actors. This contrasting expectations make us agnostic about the effectiveness of fiscal policy conditional on a crisis in non-EMU countries.

Hypothesis 2: Financial crises have increased CBI in European countries unconditional of changing debt levels.

\footnotetext{
${ }^{12}$ Recent research has shown that fiscal 'gimmickry' in Europe has undermined the validity of the Maastricht convergence criteria (Alt et al 2014). We will not dive into this interesting stem of research in this paper.
} 


\section{Effect of Crises on Political Reforms: Legislative Scrutiny}

Institutional reforms in any political system can take the form of economic restructuring or, otherwise, political changes. The literature often considers whether inequality is a necessary trigger of institutional reforms. Here, we follow Haggard and Kaufmann (2012) in arguing that there are mechanisms through which distributional power conflicts - which become most often acute in times of financial stress - are translated into political changes.

In a cooperative context like the European Council, which is the highest forum of EU decision making, distributive conflicts are really a tension between those that want to move away from the status quo and those that want to remain on the current bargaining terms. We assume that, as any exogenous shock, an economic crisis worsens the political status quo, moving it away from the preferences of the key social groups and therefore the core of the polity. Obviously, the interests of these actors might also diverge more and more. If the polity decides by unanimity (as the European Union does) on institutional reforms, the potential for introducing new rules depends on whether the possibly expanding core 'swallows up' a newly located status quo. Evidently, no reforms are possible with a status quo located inside the set of (Pareto-optimal) solutions. ${ }^{13}$

Given the voting rules in the Union, crisis management and decision making may be dictated by the members which are closest to the status quo. This is especially the case since the 2007 Lisbon Treaty, which has brought a supranationalist twist to the intergovernmental negotiations. As Article 9B of the Treaty makes clear, the President does not depend on the laggard members of the organization: "The European Council shall elect its President, by a qualified majority, for a term of two and a half years, renewable once". ${ }^{14}$ This has increased

\footnotetext{
${ }^{13}$ This regularity is in line with institutionalist analyses of the unanimity rule that examine the relationship between preference heterogeneity and political change. According to Colomer (1999: 548), the potential for policy reform depends considerably on the location of the status quo: "a large distance from the status quo to the actors' ideal points offer many possibilities for choice to the decision-makers and may make the decision relatively open and uncertain." Under majority rule and multi-dimensional policy spaces, the existence of a core is not guaranteed (Greenberg 1979). However, there is a close negative relationship between the size of the core and the size of the win-set (Drüner et al. 2013, Tsebelis 2002). Accordingly, although the core expands, this change might be offset through the move of the status quo away from the ideal points of the committee members.

${ }^{14}$ See main text of the treaty at http://www.consilium.europa.eu/documents/treaty-of-lisbon.
} 
the chance that a President pursues interests that are not in line with the most nationalist member states, but rather opts for policy outcomes which the member states with supranationalist leanings may favour.

While this discussion might lead some to think that economic crises cannot move the parameters of political change in the EU (Armingeon and Baccaro 2012), in our view crises activate some types of demand for political change. Following the notion of Colomer (1999), financial crises can trigger reforms as long as they move the policy 'reference point' to a location that is sufficiently bad in comparison to reform options. Citizens hold governments responsible for the economic turmoil, so they will demand changes that lower the risk of a new crisis from them or their successors. So, at minimum, parliaments - as popular representations for the most part - should constrain their executives to provide further transparency and more reports on the decision making process in Brussels.

The European integration literature that studies information provision to national legislatures is generally in support of this conjecture. Winzen (2013), for example, notes that the increase in instruments for parliamentary control of EU institutions since the 1990s shows that national parliaments have reacted to the challenges of European integration. ${ }^{15}$ Similarly, in a study of debates at plenary parliamentary sessions in northern Europe, de Wilde (2014) identifies the increasing authority of the EU as a main driver of parliamentary scrutiny mechanisms. What we think needs to be incorporated in these considerations is the influence of economic crises, and in particular the potential mechanisms behind demand for $\mathrm{EU}$ oversight institutions that financial events can activate. In the absence of economic stress, legislatures can avail executive constraints and propose more political checks to EU institutions. After all, voters are aware that legislatures are the signators of governmental instruments (e.g. currency pegs and budgets) that come with international treaties. Consequently, voters are supportive of more institutional accountability as long as national

\footnotetext{
${ }^{15}$ The author writes: "there is reason to believe that these reactions have, to some extent, been driven by parliamentary ambitions to secure a role in a deepening Union. While adaptation does not bring back authority transferred to the EU level, it enables domestic legislatures to play a role in decision-making via their national governments" (Winzen 2013, p. 318).
} 
institutions work responsibly (Armingeon and Ceka, 2014). By contrast, during a crisis legislatures have less social capital, and therefore less power to contest their government. Like executives, members of parliaments face high electoral constraints at the outbreak of the crisis, and will try to expose themselves the least to the public and the EU. Parliaments will then demand less or no political changes to the way EU institutions are governed.

This said, supranational economic obligations can make an important difference on demand for political reforms at the time of a crisis. Conditional on a severe economic shock, we contend that only parliaments in independent monetary systems have the leeway to withdraw or halt demands for political reforms. These systems are free to do so because they have economies at the fringes of the Monetary Union, and their political actions have relatively little impact on any other specific EU country. Consequently, legislative demands for oversight institutions in the EU should have decreased in non-Eurozone countries at the outbreak of crises, conditional of a country being under the crisis. $^{16}$

Now consider the parliaments in the Eurozone in recent years. Like non-EMU countries, these parliaments have the incentive to withdraw pressure on their executive leaders and let them operate with lower levels of accountability at the outbreak of a crisis. Vice versa, one may expect systems less affected by a crisis to feel the duty to expand control of EU institutions. Especially when other countries are under a crisis, unaffected Euro countries should demand more transparency on how the EU allocates resources in assistance plans and bail outs. And yet, while we think these mechanisms may be in place, there are also rational calculations that justify a democratic political inertia after a crisis. From a reputation-based perspective, the international status of the Monetary Union may deter countries less involved in a crisis, and therefore more incentivized to see institutional reforms, to demand changes

\footnotetext{
${ }^{16}$ For instance, the UK required much policy involvement after the 2008 banking crush. Anticipating the political costs of exposing itself to more decision making transparency, the parliament should have deferred any political demands to the EU. By contrast, Eastern European countries outside of the Euro that suffered less from the recent crisis, like Poland, were likely concerned with "the activity of statutory auditors and entities authorized to audit financial statements and public supervision of EU activities" (see Poland's Komisja Nadzoru Audytowego [Audit Oversight Commission], 2013 Report. http://www.mf.gov . pl/documents/764034/3811889/20130417_SPRAWOZDANIE_KNA_za_rok_2012_EN.pdf) .
} 
in the European status quo that would 'shame' laggard Euro countries (Checkel 2005). As Mansfield and Pevehouse (2006: 144) note, reneging the recognized rules upon which the European Community is based on can damage each member state's international integrity. Thus, we expect that the trade-off of parliaments' demand for more EU accountability is the risk of depressing the governments in crisis-countries upon which the common currency relies. Recent international relations research has found reputation concerns critical to explain the behaviour of international organizations (Tomz 2003). Maintaining the credibility of the same currency should then incentivize Euro countries to halt demands for more oversight institutions in the course of a crisis.

Hypothesis 3: Financial crises have decreased the legislative demand for oversight institutions after the war, but had no effect in EMU countries after the Maastricht Treaty.

One may finally ask whether fiscal policies can influence the demand for political reforms at the time of a crisis. Countries that can afford social spending at the time of a crisis can expand fiscal policies to compensate public outrage. This strategy should release electoral pressure, and allow parliaments to pursue tighter control of the executive. Therefore, generally, we expect fiscal troubles and financial crises to shape political demands together. However, we also expect fiscal policy to generate different externalities across EMU and non-EMU countries in the post-Maastricht years. In the monetary union, a country's fiscal policy is subject to collective control, and can have spillover effects via trade, borrowing costs or in the most concerning scenario - risk of default. Consequently, to avoid capital outflows and a weak Euro, countries in the EMU have pressure to help the indebted country. This, we conjecture, resolves in less political demands from Eurozone states, even if they are less indebted or less affected by the crisis. ${ }^{17}$ The effect should be different in non-EMU countries. States with the flexibility to use fiscal instruments should be able to overcome the negative effect of the crisis on demand for reforms. Therefore, we expect non-EMU countries with

\footnotetext{
${ }^{17}$ Evidently the Stability and Growth Pact (SGP) was meant to avoid this type of forced burden sharing with the Excessive Deficit Procedure and multiple fines. However, in 2005 the SGP was reformulated and made significantly less rigid.
} 
flexible fiscal policies to propose oversight institutions at the time of a crisis.

Hypothesis 4: Financial crises have increased the legislative demand of oversight institutions conditional of increasing debt levels, especially in non-EMU countries after the Maastricht Treaty.

\section{Crises and Reforms in Europe: Historical Accounts}

We start our investigation of the institutional effects of financial crises with a qualitative overview of the economic and political reforms that have led to the current state of the EU since 1950. The most central element of our analysis is the occurrence of financial shocks, so we first need to identify the type of crisis that we want to trace. While much research in international finance is devoted to studying the 'logic of currency crises' (Eichengreen et al 1995), in this paper we focus on the economic stress generated by banking crises. ${ }^{18}$

To trace the occurrence of banking crises, we rely on the IMF data compiled by Laeven and Valencia (2012), who define "financial distress in the banking system as indicated by significant bank runs, losses in the banking system, and/or bank liquidations [followed by] policy intervention measures in response to significant losses in the banking system" (p. 4). As one would expect, banking crises often occur at delicate fiscal moments. In Laeven and Valencia's global dataset, 82 country-year observations are characterized by the cooccurrence of both banking and debt crises. Furthermore, some spillovers may be in place, as 63 starting years for a debt and 123 beginnings of severe banking (there are additionally 206 commencements of currency crises). Europe is no exception: 13 of the 19 European countries in the midst of financial crises between 1950 and 2010 had debt levels higher than 70 percent of their GDP.

However, note that the fact that banking crises have increased in the modern history of

\footnotetext{
${ }^{18}$ We prefer crises in the banking sectors over currency depreciations, because European discussions on the unitary peg have to some extent anticipated weak currency moments, and also because banking crises in Europe have generally been heterogeneous and exogenous. Moreover, because commercial banks behave as independent international agents, banking crises provide us a strictly exogenous type of crises.
} 
Europe is in stark contrast with the democratic trends observed since the end of the world wars. In the course of multiple waves of regime change and liberalization, the continent saw the end of dictatorships in Spain, Portugal and Greece in the 1970s, and the 'speedy' transition in the Eastern block and Baltic countries between 1985 and 1999. Economic transitions clearly co-vary with democratic transformations across the continent. ${ }^{19}$ Of course, the focus here is not on Europe's democratic waves nor the link between democratic movements and economic risk in specific European countries. Nonetheless, the cross-country data supports our basic assumption that crises are not isolated events, and in fact are closely connected with political change. To establish whether this can be said for EU institutions as well, we need to investigate the relationship between political reforms and economic policies at the basis of the European project.

The founding treaty that established the European Economic Community dates back to 1957, but, as Moravscik (2012) notes, Europe began building an agenda for political and monetary issues only in the 1970s. One may say that a major reason why the meetings of the European Union leaders were progressively incremented is the many debt and exchange-rate crises that affected prices, spending, and wages across the continent starting in the 1970s. With the 1973 oil shock, the Union was confronted with the challenges of rethinking its role in the global financial system after the end of the Bretton Woods regime. Under pressing circumstances, the European Commission headed by President Malfatti adopted a financial framework that started discussions on a single market. In parallel, a treaty was signed that authorized direct elections to the European Assembly. The European Council started its tri-annual meetings in the same circumstances, in 1975.

Similar steps were taken following other times of financial distress. For example, the 1979 US savings and loans crisis contributed to the 'Eurosclerosis' described by Giersch (1985). This crisis was partly reflected in the British budgetary antagonism in November 1979. At this point the path of EU integration followed two parallel lines, one of further

\footnotetext{
${ }^{19}$ More specifically, we identify six out of 13 European crises to occur in a five-year interval from a democratic regime change (see Figure A.1).
} 
economic conjunction and one of political consolidation, through further enlargement and new European Parliament elections. Comparably, the eve of the Black Monday in the second half of 1987 saw the European Commission of President Delors signing the Single European Act. Two years later, in December 1989, Delors launched a new round of intergovernmental conferences on monetary union and set up a European Bank of Reconstruction and development (EBRD) to provide assistance to Eastern European countries (Gilbert 2004). More recent crises corresponded to similar double reactions in the Union. For example, the early 1990s recession was thoroughly addressed in the economic discussions in Maastricht. At the same negotiations, the Community agreed upon the co-decision procedure according to which the European Parliament and the Council jointly adopted legislation. Finally, the 2008 crisis fostered parallel discussions on EMU decision making reforms, while splitting duties between Commission and European Council presidents. On the one hand, the power of the ECB and the European Stability Facility was strengthened. On the other hand, political powers continued being cointegrated (see Table 1).

What is particularly interesting about this process is that, despite the parallel changes of economic and political integration at the time of crises, not all member states showed the same enthusiasm for economic and political proposals. One year after the beginning of the recent Eurocrisis, Poland indicated they wished to re-open some areas of the Lisbon Treaty to negotiations, due to concerns with misrepresentation of Polish people's interests in the negotiation outcome. Similarly, the Dutch prime minister Jan-Peter Balkenende demanded a greater role for national parliaments in the EU decision-making process (Finke et al 2012: 171). To explore the positions over the contested reforms in the EU, we investigated member states' historical preferences for economic and political reform in the EU parliament. We looked at the ranges of EU reform focusing on the content of party platforms for past European Parliament elections, which we measure through Veen's (2001) Euromanifestos data. The distinguished dimensions refer to the power of the Monetary Union and the shift of 
competencies to 'Brussels.'20

Our calculation of the ranges of EU agreement follows a parametric multidimensional scaling (MDS) analysis of national positions. Figure 1 illustrates the factorized positions at six elections since 1979. ${ }^{21}$ The plots can be interpreted as the relationship between the differences in states' ideal policies on the identified dimensions. It is noticeable that across time there has been a remarkable distance between 'unsatisfied' countries (in the bottom left quadrants of the plots) and 'satisfied' countries (in the upper right quadrants). This indicates not only the presence of persistent disagreements across member states, but also the fact that some countries consistently resisted reforms more than others. The configurations also indicate that at each European Parliament elections at least one of the financially troubled countries in the Union (e.g. Italy in the 1970s, Portugal in the late 1990s, plus Greece in five of the six time points) was close to the status quo policy space. Looking at the most recent data points for 2008, the MDS evinces that the potential for reform at the spark of the sovereign debt crisis was restricted to non-EMU countries, which cluster in the bottom left quadrant of the plot (with the exception for Finland). At the same time, there were few countries whose assessment of both dimensions is positive (upper right quadrant), but that do not only include countries that suffered the crisis.

Combined with our historical discussion of the EU, the MDS exercise has three important implications. First, changes on the identified dimensions clearly emerge in the history of EU reforms. Although political issues and economic events are not easy to disentangle, they seem to be linked by the trade-off between the strengthening of the central economic

\footnotetext{
${ }^{20}$ We rely on Veen's additive EU policy scales. The EMU dimension is based on two categories: Positive or negative mentions of the ECB (Manifesto Project categories 4087; 4086) as well as the assessments of EMU and the Euro $(3151 ; 3141)$. The delegation dimension instead comprises government attitudes to three topics: European Community/Union (110; 108); Transfer of Power to the EC/EC (3011; 3021); and Competencies of the European Parliament $(307 ; 306)$. Positions are constructed by summing frequencies of quasi-sentences from European Parliament manifestos. They are scaled on each policy spectrum and computed with a logarithmic function. This function accounts for extreme positions on either side of the pre-determined policy spectrum. The range of policy scores goes from -50 to 50 , where 0 denotes ambiguity about an issue.

${ }^{21}$ The reliability of the MDS configurations is generally good and does not vary substantively if we calculate nonparametric multidimensional scales (mean stress values $=5.43 \mathrm{e}-13$ ). The preference arrangements remain similar if we use the Chapel Hill Expert Survey 2010 dataset.
} 
institutions and the increase the power of either the European Parliament or the national legislatures. Second, the clustering of non-EMU states in the reformist 'zone' of the policy debate (Figure 1) lends support to the conjecture that a main driver of political differences is the distinction between EMU and non-EMU countries. Finally, the fact that the score of countries with less troubled economies (France, the Netherlands, but also Austria) is close to countries like Greece and Spain suggests support to our conjecture that, even if countries less affected by the recent crisis should have complained about the state of the Union, there must be reasons that justify why they accepted the status quo. ${ }^{22}$ In the next section we provide a quantitative test of our conjecture with a panel data analysis.

\section{Determinants of Reforms: The Empirical Investigation}

\section{The Data}

The goal of this paper is to provide evidence that economic crises in the EU have increased the autonomy of technocratic actors and decreased political delegation in countries with monetary independence, but not necessarily in the core European countries. In order to empirically test our theoretical expectations, we need indicators of central bank independence and demand for delegation. Here we concentrate on all members of the EU as of 2010, with

\footnotetext{
${ }^{22}$ Of course, one may argue that the status quo is simply determined by deliberations in the EU intergovernmental setting, which is still based on unanimity voting. This lends the most conservative, anti-reform government veto power in case all other member states wish to change the prevailing status quo. If the antireform country only wants a minimal change, a modest reform or a more fare reaching policy change without the consent of the recalcitrant are possible outcomes (Schneider and Cederman 1994). As Colomer's (1999) general analysis of the unanimity rule shows, however, the implications of this decision making procedure reach beyond the expectation that the members which are closest to the status quo are able to dictate decision making. This is especially the case for the European Union since the Lisbon Treaty, which has brought a supranationalist twist to the intergovernmental negotiations. Our expectation that the introduction of a Council Presidency has introduced a decision making bias in favour of the group of countries therefore rests on the assumption that the Presidency and the countries supporting it have an informational advantage over the less integration inclined members of the organization. If such an asymmetry really exists, supranational agenda setting, delimited by the unanimity rule, is feasible. However, the reform potential under unanimity depends on this fallback position of the committee members. This indeterminacy offers a potential for biased decision making if the reform potential is limited and thus if status quo is relatively close to the so-called 'unanimity winset.'
} 
the exclusion of Luxembourg and Malta for which we have no sufficient data. ${ }^{23}$

Our first dependent variable is Change in central bank independence. In order to measure CBI between 1950 and 2010, we rely on several sources that together produce one high-quality indicator. For the years between 1950 and 1973, we leverage Sadeh's (2010) version of the classic Cukierman et al. (1992) measure (see also Cukierman, Miller and Neyapti 2002), which covers 72 countries for four time periods (here we use the 1950-59 and 1960-72). For the years between 1973 and 2010, we use data from Bodea and Hicks (2014). The authors updated the Cukierman et al (2002) data, and merged them with Crowe and Meade (2008) indicators for 69 countries at a two points in time (the 1980s and 2003), Jácome and Vázquez (2005) information on Latin America, and Bodea (2014)'s coverage of the central banks of Eastern and Central European countries. ${ }^{24}$

The CBI scores of Sadeh (2010) and Bodea and Hicks (2014) are both based on a weighted calculation of a list of indicators. These indicators fall into four categories that include Chief Executive Officer, Policy Formation, Objectives, and Limitations on Lending to the Government. The indices are calculated on a scale from 0 to 1, which we multiplied by a factor of 100 so that the score goes from perfect dependence (0) to perfect independence (100). As we want to study the change in independence from one year to the other, we first calculated this indicator's lag, and then the rate of CBI change. We then magnified the measure so to have a theoretical range going from -100, for complete loss of central bank independence, to +100 , for complete gain of central bank independence. ${ }^{25}$ Note that between

\footnotetext{
${ }^{23}$ The member states under consideration are the following: Austria, Belgium, Bulgaria, Cyprus,Czech Republic, Denmark, Estonia, Finland, France, Germany (West Germany until 1989), Greece, Hungary, Ireland, Italy, Latvia, Lithuania, Netherlands, Poland, Portugal, Romania, Slovenia, Slovakia, Spain, Sweden and the United Kingdom.

${ }^{24}$ Of course, because in this paper we are interested in studying EU reforms and not the heterogeneity of CBI across the world, our focus is on the subset of CBI for European countries. However, in separate investigations we ran our models on the global data as well. We find that the CBI mechanism is connected to banking crises, but that fiscal policies operate in different ways compared to our European sample.

${ }^{25}$ Note that Sadeh (2010), together with Guthmann (2011), provides CBI data also for more contemporary years. Although for the years 1973-2010 we rely on Bodea and Hicks (2014) because their data is more up-todate and comprehensive, it is worth mentioning that Sadeh (2010) and Bodea and Hicks (2014) do not always agree on the levels of CBI. For example, Sadeh's data suggests that the highest levels of CBI were scored by Estonia in the 1990s (CBI=77.82), while Bodea and Hicks (2014) calculate highest CBI for Armenia and Indonesia in the 2000s and Spain in the mid-1990s. Nonetheless, effectively the CBI indicators by Sadeh and Bodea and Hicks correlate at the Person's correlation coefficient of .8. This value indicates high
} 
1993 and 1999 all countries running up to the Euro reach levels of CBI up to 92 percent, and that from 1999 onwards all EMU countries are assigned a CBI score of 86 percent. ${ }^{26}$

Our second dependent variable is a measure for more or less political delegation. Because we are interested in capturing how legislatures pressure governments to be accountable at the EU level, we need a proxy of formal requests and explicit mandates from the national parliaments to the EU. The best measure we found for our purposes is the index proposed by Winzen $(2012,2013)$. The author collected codified rules contained in formal documents including constitutions, legislation, parliamentary rules of procedure, ministerial rules of procedure or other types of official documents across European countries since 1953. The large amount of information is related to legislative access and processing of information, and altogether provides indicators of 'oversight institutions' that parliaments have adopted to fight the organization and the political constraints that it creates. While Winzen reports actual numbers of, for example, memoranda and reports to the European Affairs Committees, her aggregates the indicators into a standardized index. The index scores go from 0 until 1.75 for the EU countries under consideration, and show sensible differences across states and times. We take the yearly rate of this index to create the variable Change in Oversight Institutions. $^{27}$

The main factor that we investigate in this paper is the occurrence of a financial crisis. The literature tend to distinguish two types of crises: banking crises and currency crises. We focus here on banking crises in European countries for the same reasons that we highlighted in the previous section. Using the indicators from the Laeven and Valencia (2008, 2012)

consistency, and should not be undervalued given that several measures of central bank law tend to disagree. For example, the indicator developed by Grilli, Masciandaro, and Tabellini and colleagues and the so-called Eijffinger-Schaling index are hardly uniform nor comparable.

${ }^{26}$ Countries that were integrated in the EMU since 1993 and adopted a currency peg to the Euro in 19992000 were Austria, Belgium, Finland, France, Germany, Ireland, Italy, Netherlands, Portugal and Spain. Greece joined in 2001, Slovenia in 2007, Cyprus (and Malta) in 2008, and Slovakia in 2009. Denmark adopted the European Exchange Rate Mechanism but not the currency, while Bulgaria, Czech Republic, Hungary, Poland, Romania, Sweden and the United Kingdom are not integrated in the EMU.

${ }^{27}$ Winzen (2012) describes the weighting of the different 'dimensions' that he identifies across all the procedures and rules. In substantive terms, the index has a theoretical minimum of zero and a theoretical maximum of 3. See Winzen (2012, pp. 661-662) for a detailed discussion of the aggregation. 
IMF dataset, we construct a binary variable Banking Crisis that takes the value of one if a country experienced financial distress in the banking system, and zero otherwise. We lag this variable by one year, to warrant endogeneity concerns. Note that we also construct a binary variable for currency crises, which we exploit later to check the robustness of our findings with the banking crises. ${ }^{28}$ Given our conditionality argument with respect to debt, we also use a measure of public debt to GDP. We collected this indicator from Abbas et al (2011) and updated the missing values for the recent years with the OECD debt to GDP ratio values (OECD 2014). The debt measure ranges from 1 to 216.9, with highest values in the 1950s in the United Kingdom but also the 1990s in Bulgaria. To facilitate the interpretation of this measure, we split the variable and report the coefficient for Debt: High, which takes the value of 1 if a country's debt is beyond the sample median, and zero otherwise.

The distribution of these variables is telling in itself. CBI changes have occurred quite regularly in European countries, and so have changes in legislative demands for oversight institutions. However, these events happened following different paths and at different times. European countries have overall increased CBI after crises, such as in the case of Spain after 1975 and Sweden after 1993. However, no EMU country - as expected - changed the CBI in the past fifteen years, while countries like Bulgaria or Slovakia made use of this policy during the 2000s (Figure A.2). Moreover, it is noticeable that high debt levels and crises do not occur when CBI changes. As we conjecture, governments may be using CBI to reinsure investors, but not to compensate peaks in fiscal deficits.

The distribution of change in demands for oversight institutions, however, presents different patterns (Figure A.3). New EU member countries like Greece and Cyprus saw an increase of oversight institutions in the late 1990s. Arguably, parliaments in these countries increased political control of executives at this time, because so many economic sacrifices were being demanded from them by the Union in the run-up to the Euro. However, no more

\footnotetext{
${ }^{28}$ Laeven and Valencia (2012: 11) define a currency crisis as a "nominal depreciation of the currency visà-vis the U.S. dollar of at least 30 percent that is also at least 10 percentage points higher than the rate of depreciation in the year before" (ibid.: 11).
} 
institutions are observable neither in these countries nor in 'safer' countries (e.g. Germany) during the 2008-10 crisis years. By contrast, non-EMU countries proposed more EU oversight institutions in the later 2000s, when other countries were confronting bankruptcy and default. Bulgaria and Poland, for example, increased the number of oversight institutions between 2005 and 2010 by more than 40 percent.

\section{Estimation Strategy}

We test our hypotheses on the nexus between financial crises, central bank independence and legislative demand for institutional accountability with a difference-in-differences research design. Our models measure the causal effect of crises on changes in CBI and the degree of oversight institutions by comparing pre- to post-crisis changes in our outcomes of interest. The treated group is the set of countries exposed to crises. The comparison group is the rest of the countries.

This research design is easily adaptable to our yearly-country panel data. However, in recognition of the fact that countries may not always follow parallel trends before the occurrence of crises in the years between 1950 and 2010, we control for a few possible confounders. Inflation rate is the historical yearly rate of the consumer price index retrieved from all EU Statistical Offices and compiled by Inflation Europe. ${ }^{29}$ Ideology is the party orientation of the executive from 1960 onwards. It is a variable that takes values from 1 (left-wing) to 5 (right-wing), and comes from the CPDS dataset (Armingeon et al., 2011). Finally, in separate regressions, we used logged GDP per capita (World Bank Indicators 2014) and a measure of trade openness as the sum of trade divided by GDP (IMF 2014). Note that the results remain largely unchanged if we integrate also these two additional control variables.

Our main model specification in the difference-in-differences framework is

$$
\mathrm{T}_{i t}=\alpha+\beta C_{i t}+\gamma \mathbf{X}_{i t}+\eta_{i}+\theta_{t}+\epsilon_{i t}
$$

\footnotetext{
${ }^{29}$ See http://www.inflation.eu/inflation-rates/historic-cpi-inflation.aspx. We confirmed these values against the Eurostat values for the 2000 s.
} 
where $i$ indexes each country in the dataset and $t$ indexes the yearly periods. The measure $Y$ refers to the outcomes under analysis, which are differenced and indicate changes. ${ }^{30}$ The parameter $C$ is the occurrence of banking crises, which we lag by one year. The matrix of controls $\mathbf{X}$ has a coefficient vector $\gamma$, while $\eta_{i}$ are country fixed effects and $\theta_{t}$ are year fixed effects parameters. For the CBI regressions we expect $\beta>0$, while for the political institutions regressions, we expect $\beta<0$.

We run the regressions at the aggregate level for the whole time period, and by EMU and non-EMU subsamples after 1993, the year of the Maastricht Treaty. According to our first hypothesis, banking crises have an average significant effect across all countries that are subject to them. However, we also argued that in more recent years these effects should only be observed in non-EMU countries, which have a stronger flexibility to change their monetary policies. Similarly, we conjectured that under a crisis independent countries have generally an incentive to eclipse from the EU spotlight and halt the demand for oversight institutions. But for the subsample analyses, we predict a null finding for EMU countries, which have a lower incentive to disrupt the reputation and credibility of their EMU partners.

Finally, we modify the specification from equation 1 in models that account for the interaction between banking crises and debt. Interactions in difference-in-differences frameworks admittedly complicate the inferences of the multiplicative term. However, they allow us to estimate effects that are not just based on trends of crises but also on the alternative trends across both crisis and non-crisis states determined by changes in fiscal spending. Given our conditionality hypotheses, these interactions should generate no significant differences with respect to the $\mathrm{CBI}$ change, but they should have an effect on the less indebted and more monetarily independent European countries with respect to institutional oversight.

\footnotetext{
${ }^{30}$ Differencing also helps circumnavigating possible concerns with autoregressive errors. The Wooldridge tests indicate that the differenced variables show no autoregressivity.
} 


\section{Results}

We report our findings on the variable Change in central bank independence in Table 2. The first set of results refer to the sample of all independent countries. This includes all country-years where a European country had complete control of its economy, hence the entire series of countries that were never part of the EMU as well as all the years before an EMU country was integrated in the Monetary Union. We show the coefficients for three alternative difference-in-differences set ups: a model with only the crisis treatment; a model where we interact the Banking Crisis dummy with the Debt: High dummy; and a model where we additionally include the Inflation and Ideology variables.

The first model indicates that banking crises have positive effects on central banks' autonomy. More specifically, a shock to public and private banks is conducive to a national government providing about 6 percent more independence to central banks, although this effect only borders statistical significance at the $10 \%$ p-value. The second model introduces the effect of debt and the interaction with the banking crisis. The effect of crises is weakened, and the interaction has overall a null impact on the changes to CBI. This evidence is consistent to hypothesis that, overall, debt has not mediated the effect of crises in European countries. If anything, the stages of economic integration in Europe came before the increases in debt, through which government financed their efforts to match the standards superimposed by Brussels. In the third model we account for pre-determined effects of inflation and executive ideology on CBI change. However, the results remain overall consistent with out findings.

Our second difference-in-differences analyses on CBI change focus on the subset of country-year observations for independent (non-EMU) states after the enactment of the Maastricht Treaty. The results that leverage the single effect of lagged banking crises show that, among non-EMU countries, crises have a larger and statistically significant effect on CBI change. All else equal, a shock like the Swedish crisis in the mid-1990s has increased CBI by 13.5 percent. This effect is however less clear when we explore the interaction with 
debt crises. The results are unaltered if we include the additional confounding variables: keeping all other variables are the mean, we detect a significant positive effect of facing a banking crisis with a government's decision to increase CBI by roughly 15 percent. Our statistical findings overall confirm the argument in the literature that European countries have responded to crises with monetary instruments, and that this mechanism has helped also independent countries in most recent years. The United Kingdom, for example, delegated a small yet important amount of additional power to its central bank in 2009. We also find that conditional of integrating in strict monetary treaties such as the EMU, crises have no significant effects on CBI, which is directed at the supranational level.

We argued that, although on the economic side the EU can constrain the power of its core member states, politically it can create incentives to support each other at the time of a crisis, especially among countries that rely on the political credibility of the Union as a whole. In order to test the second part of our argument, we ran regressions of Change in Oversight Institutions with the same difference-in-difference approach. Table 3 presents our results, which are focused on the same samples studied so far. The model that investigates the single effect of Banking Crisis shows that a shock to the banking system depresses the legislative control on EU executive affairs by approximately 3 percent (5 points in a scale from 1 to 175). This effect is magnified in systems where debt is particularly high: in the interaction model, a lagged banking crisis decreases the index of oversight institutions by 10 points. Moreover, we find that fiscal debt mediates the effect of crises as we expected. Specifically, a crisis that impinges on countries that can expand their fiscal policies increases the oversight institutions on the EU. ${ }^{31}$ This evidence corroborates our argument that political decisions are bound to the level of spending that governments can afford to compensate the consequences of crises. Legislatures allow increases in expenditure at the cost of further controlling governments' behaviour. By contrast, governments that decrease spending are less bound to legislative controls.

\footnotetext{
${ }^{31}$ See Figure A.4 for the marginal effect plots of the influence of crises on the two outcome variables, and Figure A.5 for the effect plots of crises conditional on the continuous measure of debt.
} 
We finally explore the effect of crises for the subset of non-EMU countries after the Maastricht Treaty. We find that a crisis declines the likelihood of changes in oversight institutions significantly, also under the conditions of increasing debt levels. These results are overall consistent with our theoretical prediction that legislatures in states outside the Eurozone are more willing to forgo control over the executive at critical economic times. By contrast, our tests on the EMU-only sample (in the Appendix) indicate that this effect is neither substantial nor significant. Evidently the largest differences across oversight institutions or the EU are detected by occurrence of a financial crisis. However, in more recent years, the main difference is to be found in the cleavage between EMU and non-EMU countries.

\section{Robustness}

Our results are robust to a number of sensitivity tests. In Table A.1 and Table A.2 we show that our CBI estimations of the effect of crises between 1950 and 2010 do not generally suffer from omitted variable bias, since including usual control indicators like GDP and trade openness in the regression equation does not change the significant effect of the lagged baking crisis on both CBI and Oversight Institutions. The only relevant alteration is the loss of significance of the interaction term between crises and debt in the analysis of parliamentary oversight institutions. However, this is likely an artifact of the multi linearity between trade openness, GDP and debt.

In alternative models reported in Table A.3 and Table A.4 we test the sensitivity of our results to the sample definition. Overall our findings are consistent if we consider all country-years without dropping the EMU country-years (columns 1-3). Even if balance the sample and study only the period between 1993 and 2010, we still find the positive (but not significant) effect of crises on CBI, while the effect on change of oversight institutions is significant and negative (columns 4-6). Finally, the results for EMU countries (columns 7-9) are consistent with our expectation that these countries should not have changed neither 
their CBI nor their demand for more supranational controls after the Maastricht Treaty.

One concern with our estimations is that our models may not purge spillover effects, despite the country and year dummies that are required by the difference-in-differences approach. One way to address this econometric concern is to run population average models, which are typically used when one wants to study average treatments on the overall population of states (Zorn 2001). The method typically used to estimate population average models is the generalized estimating equations approach, which is flexible to different variance structures. In Table A.5 and Table A.6 we report the results of these models of the change of CBI and oversight institutions, respectively. The estimates, which we calculate for independent correlations and Huber-White standard errors, support our main findings. The population-averaged regressions even strengthen the statistical significance of our negative effects of crises on CBI, both in the singular (banking crisis) and the interaction (crisis and debt) models.

We also tested whether our inferences on the demand for oversight institutions in the EU are driven by the specific distribution of the index that Winzen (2013) proposes. In Table A.7 we report results for a slightly alternative index based on the same qualitative indicators (Winzen 2012). The results remain substantially unchanged, as the magnitude of the effects is marginally larger. Given the fact that Winzen's index is bound between 0 and 1.75 , we also ran fixed effects tobit models. We find that both general sample of European independent countries since 1950 and the specific sample of non-EMU countries stop strengthening legislative powers vis-à-vis the EU after a crisis. By contrast, we find that the 2008 crisis in EMU countries has not induced any significant decline in legislative delegation (Table A.8).

We pushed out causal inferences further by investigating whether our results are driven merely by considerations of sovereignty that parliaments raised at each time the EU enlarged. In other words, we need to check that truly exogenous banking crises are the drivers of economic and political reforms, and not crises linked to market concerns with the reper- 
cussions of EU conditionality at the time of further integration. We then purge the crises indicators with an instrumental variable that takes values of 1 to 3 , with 1 indicating the most primitive level of accession to the EU, while 3 corresponds to full accession (Winzen 2012). Table A.9 reports the second stage least squares results for both the CBI and the legislative oversight institutions regressions. We find that the effect of crises on CBI change is indeed mitigated by whether countries are fully accessed to the EU. However, our inference that banking crises drives the level of legislative control of EU policy making remains robust.

As a further set of analyses, we ran our models substituting banking crises with currency crises. Our conjecture suggests that systems with monetary independence should have incentives to increase monetary policy and decrease parliamentary overview of EU institutions when money is scarce and investments are low. However, in the instance of a currency attack from abroad, one may expect all countries - so both the ones with monetary independence and the ones in the EMU - to react decisively to the shock with a change of CBI. Moreover, a currency crisis in the EMU may constitute a placebo test to the effect of banking crises on political reforms, because currency crises should activate reactions precisely to defend the political credibility of governments more connected in the Union, and less the non-EMU countries. Table A.10 and Table A.11 corroborate these expectations, therefore providing evidence that the mechanisms behind monetary autonomy and political reputation in the Union are in place in the occurrence of crises.

\section{Interpretation and Discussion}

The evidence provided by our empirical estimations indicates that financial crises are conducive to reforms in the European Union, but not always and not at all conditions. Moreover, it lends support to our theory it is not the democratic deficit but rather a threat of economic reputation and international credibility that may stall these reforms. From a within-country point of view, our findings are easy to understand with regards to CBI reforms. For example,

Estonia's commitment to more CBI in the early 1990s was triggered by credit shrinkage of 
the banking sector, which came hand in hand with public administration reform and the reinforcement of the judiciary in $1998 .^{32}$ Similarly, the Italian economic crisis in the early 1990s prompted a vigorous reaction. Banca d'Italia ${ }^{33}$ reports that

In the summer of 1994 a monetary tightening inaugurated a period of rigour. In 1995, a year that saw another foreign exchange crisis, the discount rate reached 9 per cent. The resolute action of the Bank of Italy in these years helped to reduce inflation expectations. Price rises having been curbed, in 1996 monetary conditions were eased. Renewed confidence, both domestically and internationally, permitted a reduction in long-term interest rates and led to a drastic cut in interest payments on the public debt; so monetary policy contributed significantly to public financial adjustment. On the strength of these efforts, Italy was in the first wave of countries to adopt the single European currency.

Evidently crises-driven CBI is linked to monetary reforms in the EU. What about the mechanism behind crises and political delegation? Our results corroborate our expectation that, conditional on a crisis, the political reputation of governments upon which economic integration depends refrains parliaments from other (less affected) countries. This of course does not mean that legislatures in Euro countries that were not affected by the recent 2008 crisis did not raise their voice for more institutional controls over the EU executive affairs. Figure 2 clearly shows these patterns. On the run-up to the Eurocrisis, Euro countries like France and Greece had parallel levels of demands for oversight institutions. ${ }^{34}$ However, as the crisis of 2008 begins (red bar), one can see the spike of legislative concerns in France vis-'a-vis the more conservative parliament in Greece. We observe a similar trend in other countries like the Netherlands and Belgium. The former was certainly a country where legislative forces complained for misuse of power and miscommunications between the national and the EU level. After two large inquiries, the Dutch parliament established that it should receive two issue reports every year by National Court of Audit about measures concerning the financial crisis. ${ }^{35}$ At the same time, however, one may say that the reaction was less

\footnotetext{
${ }^{32}$ See EU Enlargement Report on Estonia at http://ec.europa.eu/enlargement/archives/pdf/key_ documents/1998/estonia_en.pdf.

${ }^{33}$ History of Banca d'Italia at https://www.bancaditalia.it/bancaditalia/storia/europa; internal\&action=_setlanguage. action?LANGUAGE $=$ en

${ }^{34}$ This is also what in the difference-in-differences framework is called the parallel trends assumption.

${ }^{35}$ OECD Public Expenditure Committee. 2012. http://www. oecd.org/gov/budgeting/49793706.pdf.
} 
striking as it could have been if the Netherlands had been less integrated in the Eurozone. After all, reforms such as the 2010 Crisis and Recovery Act included, among others, committee contact with the EU and parliamentary questions. However, all these reforms depend on negotiations at the EU level as well. In other words, the Netherlands government was refrained to implement these provisions without the European Parliament approval. ${ }^{36}$

As evinced in the quantitative analyses, the starker differences in parliamentary behaviour emerge if we compare EMU and non-EMU countries, for example Bulgaria versus Cyprus (Figure 2). The increase in oversight institutions in Eastern European states can be - and has been - linked to the timing at which non-EMU countries adopted EU policies. Evidently, giving up more sovereignty is counterbalanced with more oversight efforts. Our mechanism however indicates that the occurrence (or non-occurrence) of crises reinforces this. This is consistent with what we observe in the data: More independent states - like Bulgaria - demanded more legislative controls and accountability once the crisis broke out in its neighbour European countries. For example, the Bulgarian Committee on European Affairs and Oversight of the European Funds prepared an Annual Work Program, which included parliamentary observation and control of European "financial instruments, humanitarian aid and crisis response." 37 By contrast, countries that signed up to the Euro - like Cyprus - proposes no further parliamentary controls. This decision importantly affected not only the fate not only of its domestic politics but also signalled constraints to other governments. In fear of protecting the credibility of the EU, Euro countries have accepted the positions of these more sensitive countries.

\footnotetext{
${ }^{36}$ U.S. Congressional Research Service. 2010. The European Union's Response to the 2007-2009 Financial Crisis. http://fas.org/sgp/crs/row/R41367.pdf.

${ }^{37}$ See Annual Report on the Absorption of European Funds in the Republic of Bulgaria. 2012. page 26. http://parliament.bg/pub/cW/201202090951472011_Annual\\%20Report_EU_Funds \\%20-\ $\% 20$ Resume_EN.pdf.
} 


\section{Conclusion}

The original debate on the feasibility of reforms in the EU started out with Scharpf (1988), who speculated that the European Union finds itself in a 'joint decision making trap.' In his view, there are always governments that profit from the current status quo which renders it impossible to change the rules of the game. The prediction is, however, misleading if one considers that powerful countries have barely moved from the status quo themselves, even when it was not their most beneficial position. Moreover, it does not provide a general understanding of what combines and distinguishes members in supranational organizations at the outbreak of events like the 2008 sovereign debt crisis. Evidently, we still do not know whether economic crises can either break or solidity reform paths in international organizations like the EU.

Contributing to this debate, Kurpas (2007: 3) believes that: "those who see the European Union as another tool in the box of the nation state have clearly won the case, which is unlikely to be without consequence for the prospect of future integration." Dougan (2008: 698) moreover maintains that "a relative resurgence in intergovernmental influence within the functioning of the Union" is possible. As we have shown, these observations are only partially correct as incentives for monetary credibility and currency reputation against the wishes of some member states has introduced the possibility of supranational agenda setting. The possibility to move the outcomes closer to the ideal points of EU agents like the ECB adds to the frustration of those who generally believe that the organization suffers from a democratic deficit and that increased legitimization of its policy outcomes is mandatory in times of crisis and crisis decision making.

Using a different range of empirical data and methods, we have shown how financial crises influenced economic and delegation policies in post-war Europe. We showed that severe economic distortions may not only result in beneficial policy changes, as Drazen and Grilli (1993) demonstrate, but that economic shocks can also provoke institutional distortions, especially in the most integrated and reciprocally dependent countries of the EU. While key decisions in this international organization will continue following unanimity for 
the most part, reform proposals will generally benefit some member states more than others. In our view, the Union can only rectify this imbalance through the decision to delegate the drafting of intergovernmental conferences to institutions and actors that have not profited from recent institutional reforms to a disproportional extent. We showed that national parliaments from some member states at the periphery of the Union have increasingly developed ideas on how the drift of executive power to Brussels can be curtailed and how a European fiscal policy can be democratically legitimized at the time of a crisis. However, such a scenario assumes that the EU-skeptical shift in the public preferences witnessed since more than a decade does not dramatically accelerate. A growing heterogeneity of preferences would indeed render adequate institutional reforms in the European Union unfeasible. 


\section{References}

Abbas, S. M. Ali, Nazim Belhocine, Asmaa El-Ganainy, and Mark Horton. 2011. Historical Patterns and Dynamics of Public Debt. Evidence from a New Database. IMF Economic Review 59(4): 717-742.

Acemoglu, Daron, Simon Johnson, James Robinson, and Pierre Yared. 2008. Income and Democracy. American Economic Review 98(3): 808-42.

Acharya, Amitav. 1999. Southeast Asia's Democratic Moment. Asian Survey 39(3): 418-432.

Alemàn, José and David D. Yang. 2011. A Duration Analysis of Democratic Transitions and Authoritarian Backslides. Comparative Political Studies 44(9): 1123-1151.

Alesina, Alberto, and Allen Drazen. 1991. Why Are Stabilizations Delayed? American Economic Review 81(5): 1170-1188.

Alesina, Alberto, Dorian Carloni and Giampaolo Lecce. 2011. The Electoral Consequences of Large Fiscal Adjustments. NBER 17655.

Alt, James, Lassen, David Dreye and Wehner, Joachim. 2014. It Isn't Just about Greece: Domestic Politics, Transparency and Fiscal Gimmickry in Europe. British Journal of Political Science 44(04): 707-716.

Armingeon, Klaus, Romana Careja, Panajotis Potolidis, Marlene Gerber and Philipp Leimgruber. 2011. Comparative Political Data Set III 1990-2009. Institute of Political Science, University of Berne.

Armingeon, Klaus and Baccaro, Lucio. 2012. Political Economy of the Sovereign Debt Crisis: The Limits of Internal Devaluation. Industrial Law Journal 41(3): 254-275.

Armingeon, Klaus and Ceka, Besir. 2014. The loss of trust in the European Union during the great recession since 2007: The role of heuristics from the national political system. European Union Politics 15(1): 82-107.

Bernhard, William, Broz, J. Lawrence and Clark, William Roberts. 2002. The Political Economy of Monetary Institutions. International Organization 56(4): 1-31.

Bodea, Cristina and Hicks, Raymond. 2014. Price Stability and Central Bank Independence: Discipline, Credibility and Democratic Institutions. Forthcoming at International Organization.

Bodenstein, Thilo and Gerald Schneider. 2006. Capitalist junctures: Explaining economic openness in the transition countries. European Journal of Political Research 45(3): 467-497.

Bormann, Nils-Christian and Matt Golder. 2013. Democratic Electoral Systems Around the World, 1946-2011. Electoral Studies 32: 360-369.

Broz, Lawrence J. 2002. Political System Transparency and Monetary Commitment Regimes. International Organization 56(4): 861:887.

Bueno de Mesquita, Bruce; Alastair Smith, Randolph M. Siverson, James D. Morrow. 2003. The Logic of Political Survival. Cambridge, Mass.: MIT Press. 
Bueno de Mesquita, Bruce, and Alastair Smith. 2010. Leader Survival, Revolutions and the Nature of Government Finance. American Journal of Political Science 54: 936-950.

Colomer, Josep M. 1999. On the Geometry of Unanimity Rule. Journal of Theoretical Politics 11(4): 543-553.

Crowe, Christopher and Ellen E. Meade. 2008. Central bank independence and transparency: Evolution and effectiveness. European Journal of Political Economy 24(4): 763-777.

Cukierman, Alex, Webb, Steven B., Neyapti, Bilin. 1992. Measuring the independence of central banks and its effect on policy outcomes. World Bank Economic Review 6.

Cukierman, Alex. 1992. Central Bank Strategy, Credibility and Independence: Theory and Evidence. Cambridge, MA: MIT Press.

de Bromhead, Alan, Barry Eichengreen, Kevin H. O'Rourke. 2013. Right-Wing Political Extremism in the Great Depression. Journal of Economic History 73(2): 371-406.

de Wilde, Pieter. 2014. The Operating Logics of National Parliaments and Mass Media in the Politicisation of Europe. Journal of Legislative Studies 20(1): 46-61.

Dougan, Michael. 2008. The Treaty of Lisbon 2007: Winning Minds, Not Hearts. Common Market Law Review 45(3): 617-703.

Drazen, Allan and Vittorio Grilli. 1993. The Benefit of Crises for Economic Reforms. American Economic Review 83(3): 598-607.

Drüner, Dietrich, Heike Klüver, Ellen Mastenbroek and Gerald Schneider. The Core or the Winset? Explaining Decision-Making Duration and Policy Change in the European Union. Unpublished Manuscript.

Eichengreen, Barry, Rose, Andrew K. and Wypolsz, Charles. 1996. Contagious currency crises. NBER Working Paper No. 5681. Cambridge, Massachusetts.

Epstein, David. L., Robert Bates, Jack Goldstone, Ida Kristensen, and Sharyn O'Halloran. 2006. Democratic Transitions. American Journal of Political Science 50(3): 551-569.

Finke, Daniel, Thomas König, Sven-Oliver Proksch, and George Tseblis. 2012. Reforming the European Union: Realizing the Impossible. Princeton: Princeton University Press.

Follesdal, Andreas and Simon Hix. 2006. Why there is a democratic deficit in the EU: A response to Majone and Moravcsik. Journal of Common Market Studies 44(3): 533-562.

Frankel, Jeffrey A. 2005. Mundell-Fleming Lecture: Contractionary Currency Crashes in Developing Countries. IMF Staff Papers, 52(2): 149-192.

Frieden, Jeffry A. 2002. Real Sources of European Currency Policy: Sectoral Interests and European Monetary Integration. International Organization 56(4): 139-168.

Giddens, Anthony. 2012. In Europe's dark days, what cause for hope? The Guardian, January 25. http://www.guardian.co.uk/world/2012/jan/25/anthony-giddens-europe-dark-dayshope?newsfeed=true.

Giersch, Herbert. 1985. Eurosclerosis. Kiel Discussion Papers no. 112, Kiel. 
Guthmann, Kai. 2011. Political and Institutional Foundations of a Strong Currency: Evidence from Central and Eastern Europe. Unpublished master thesis, University of Konstanz.

Greenberg, Joseph 1979. Consistent Majority Rules over Compact Sets of Alternatives. Econometrica, 47: 627-636.

Habermas, Jürgen 2011. Zur Verfassung Europas. Ein Essay. Berlin: Suhrkamp.

Habermas, Jürgen 2013. Demokratie oder Kapitalismus? Vom Elend der nationalstaatlichen Fragmentierung in einer kapitalistisch integrierten Weltgesellschaft. Blätter für deutsche und internationale Politik 58(5): 59-70.

Haggard, Stephan and Robert R. Kaufman. 1995. The Political Economy of Democratic Transitions. Princeton, NJ: Princeton University Press.

Haggard, Stephan and Robert R. Kaufman. 2012. Inequality and Regime Change: Democratic Transitions and the Stability of Democratic Rule. American Political Science Review 106(3): 495-516.

Hielscher, Kai and Gunter Markwardt. 2012. The Role of Political Institutions for the Effectiveness of Central Bank Independence. European Journal of Political Economy 28(3): 286-301.

Hix, Simon. 2008. What's Wrong with the European Union and How to Fix it. London. Polity.

Kapstein, Ethan Barnaby. 1992. Between power and purpose: central bankers and the politics of regulatory convergence. International Organization 46(1): 265-287.

Kennedy, Ryan. 2010. The Contradiction of Modernization: A Conditional Model of Endogenous Democratization. Journal of Politics 72(3): 785-798.

Jàcome, Luis I. and Francisco Vàzquez. 2005. Any Link between Legal Central Bank Independence and Inflation? Evidence from Latin America and the Caribbean. IMF Working Paper 05/75.

Kindleberger, Charles P. 1986. The World in Depression, 1929-1939. Berkley: University of California Press (2nd, revised and enlarged edition).

Kurpas, Sebastian. 2007. The Treaty of Lisbon: How Much 'Constitution' is Left. CEPS Policy Brief, No. 148.

Laeven, Luc and Fabiàn Valencia 2008. Systemic Banking Crises: A New Database. IMF Working Paper No. 08/224.

Laeven, Luc and Fabiàn Valencia. 2012. Systemic Banking Crises Database: An Update. IMF Working Paper No. 12/163.

Lipset, Seymour Martin. 1959. Some Social Requisites of Democracy: Economic Development and Political Legitimacy. American Political Science Review 53 (1): 69-105.

Majone, Giacomo. 1996. Regulating Europe. London: Routledge.

Majone, Giacomo. 1998. Europe's 'Democratic Deficit': The Question of Standards. European Law Journal 4(1): 5-28.

Moravcsik, Andrew. 2002. In Defenxe of the 'Democratic Deficit': Reassessing the Legitimacy of the European Union. Journal of Common Market Studies 40(4): 603-34. 
Moravcsik, Andrew. 2012. Europe After the Crisis: How to Sustain a Common Currency. Foreign Affairs 91: 3.

Obstfel et al 2004.

Polillo, Simone and Mauro F. Guillèn. 2005. Globalization Pressures and the State: The Worldwide Spread of Central Bank Independence. American Journal of Sociology 110(6): 17641802.

Przeworski, Adam, and Fernando Limongi. 1997. Modernization: Theory and Facts. World Politics 49 (2): 155-83.

Przeworski, Adam, Michael E. Alvarez, Josë Antonio Cheibub, and Fernando Limongi. 2000. Democracy and development: Political institutions and material well-being in the world, 1950-1990. Cambridge, UK: Cambridge University Press.

Rodrik, Dani. 1996. Understanding Economic Policy Reform. Journal of Economic Literature 34:(1): 9-41.

Saalfeld, Thomas. 2005. Deliberate Delegation or Abdication? Government Backbenchers, Ministers and European Union Legislation. The Journal of Legislative Studies 11(3): 343-371.

Sadeh, Tal 2010. Hard Currencies for Hard Times. Terror Attacks and the Choice of Monetary Anchors. Defence and Peace Economics 22(4): 367-392.

Scharpf, Fritz W. 1988. The joint-decision trap: Lessons from German federalism and European integration, Public Administration 66(3): 239-278.

Schneider, Gerald and Lars-Erik Cederman. 1994. The Change of Tide in Political Cooperation: A Limited Information Model of European Integration. International Organization 48(4): 633-662.

Smith, Alastair. 2008. The perils of unearned income. Journal of Politics 70(3): 780-793.

Stasavage, David. 2011. States of Credit. Size, Power, and the Development of European Polities. Princeton: Princeton University Press.

Streeck, Wolfgang. 2011. Markets and Peoples: Democratic Capitalism and European Integration. New Left Review 73 (September-October): 63-71.

Streeck, Wolfgang 2013. Gekaufte Zeit: Die vertagte Krise des demokratischen Kapitalismus. Berlin: Suhrkamp.

Tsebelis, George. 2002. Veto Players: How Political Institutions Work. Princeton: Princeton University Press.

Ulfelder, Jay. 2009. Pathways to Political Liberalization in Dictatorships. SSNR Working Paper 1532791.

Veen, Tim. 2011. Positions and Salience in European Union Politics: Estimation and Validation of a New Dataset. European Union Politics 12(2): 267-288.

Winzen, Thomas. 2013. European integration and national parliamentary oversight institutions. European Union Politics 14(2): 297-323. 
Winzen, Thomas. 2012. National parliamentary control of European Union affairs: a crossnational and longitudinal comparison. West European Politics 35(3): 657-72.

Zorn, Christopher J. W. 2001. Generalized Estimating Equation Models for Correlated Data: A Review with Applications. American Journal of Political Science 45 (2): 470-490. 
Figures 


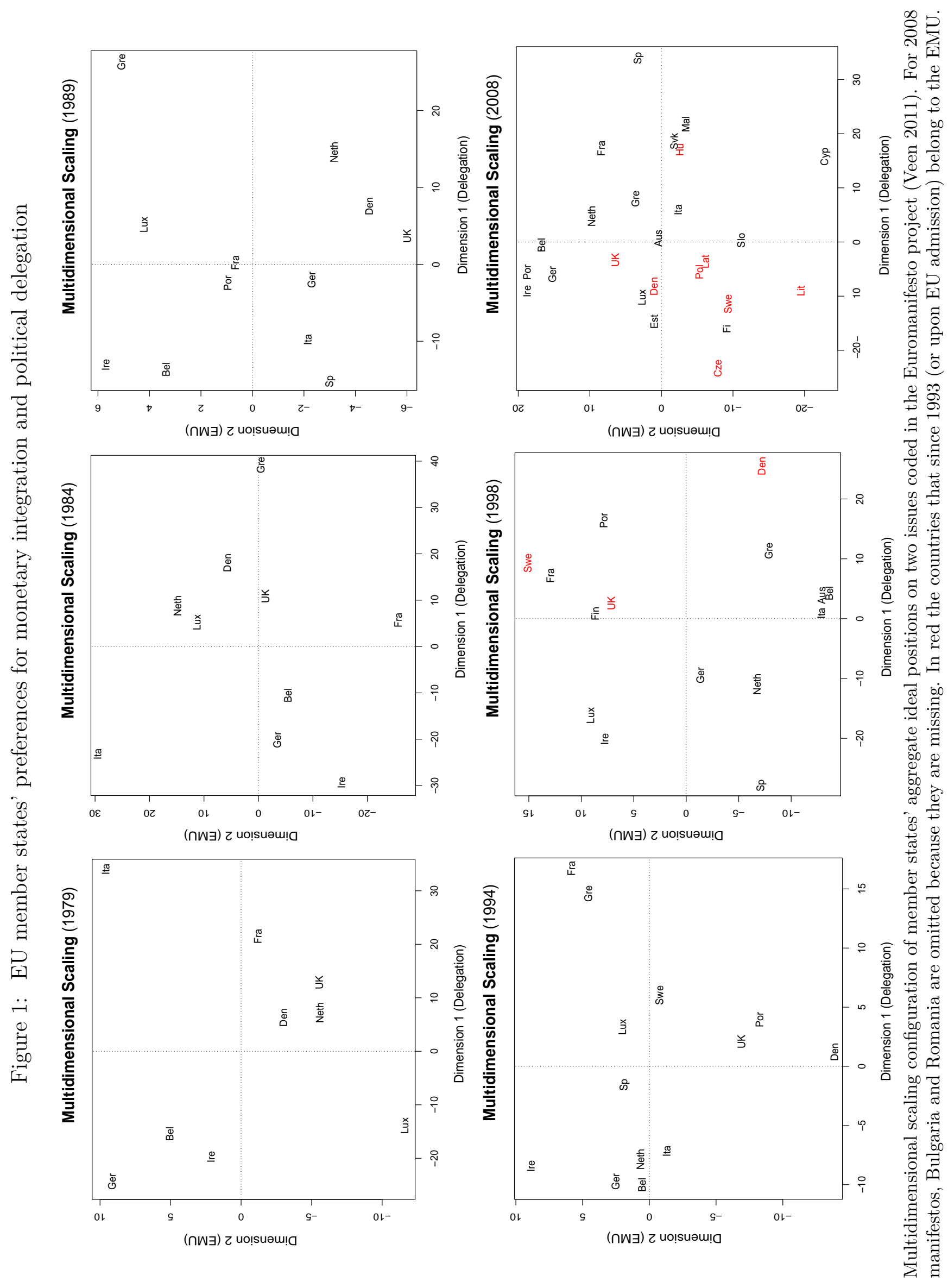


Figure 2: Pre- and post-Eurocrisis trends on legislative oversight
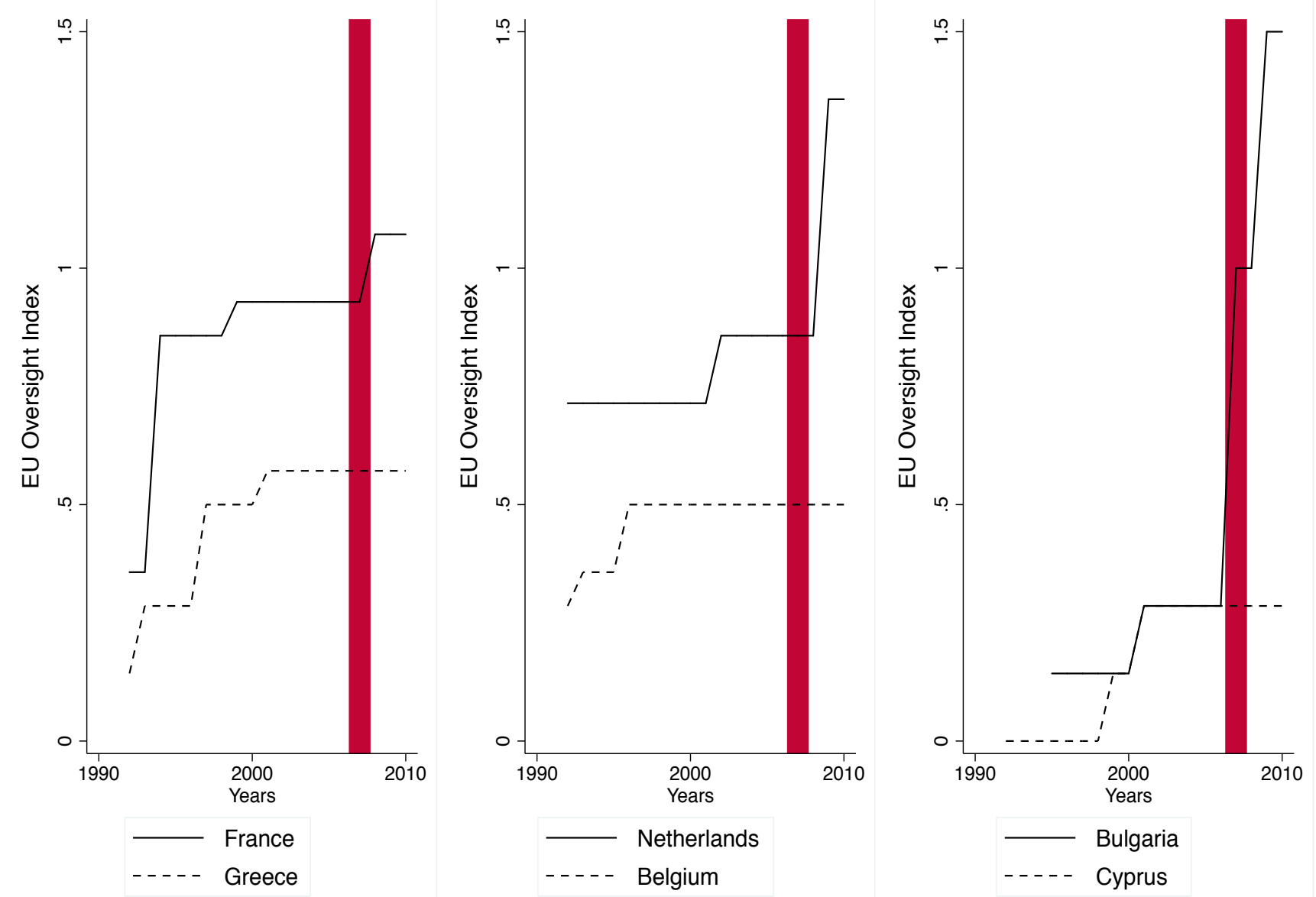

Lines correspond to the country-specific values of the institutional oversight index of Winzen (2012). The red bar corresponds to the beginning of the Eurocrisis (2008). 


\section{Tables}

Table 1: EU economic crises and institutional reforms

\begin{tabular}{|c|c|c|c|}
\hline Crises in the EU & Symptoms & Political reforms & Monetary reforms \\
\hline $\begin{array}{c}\text { 1971-76: End of Bretton } \\
\text { Woods and first oil shock }\end{array}$ & $\begin{array}{c}\text { Malfatti } \\
\text { Commission }\end{array}$ & $\begin{array}{c}\text { Paris Summit and } \\
\text { EA elections (1974) }\end{array}$ & $\begin{array}{c}\text { Currency 'snake' } \\
(1972)\end{array}$ \\
\hline $\begin{array}{c}\text { 1979-84: Second oil } \\
\text { shock }\end{array}$ & 'Eurosclerosis' & $\begin{array}{c}\text { Court of Justice and EP } \\
\text { empowerment (1980) }\end{array}$ & $\begin{array}{c}\text { EMS ECU (1979) } \\
\text { and SEA (1984) }\end{array}$ \\
\hline $\begin{array}{c}\text { 1987-91: US loan crisis } \\
\text { and 'Black Monday' }\end{array}$ & British & $\begin{array}{c}\text { New Intergovernmental Confe- } \\
\text { rences launched (1990) }\end{array}$ & $\begin{array}{c}\text { Delors EMU } \\
\text { Report (1989) }\end{array}$ \\
\hline $\begin{array}{c}\text { 1992-97: Oil price spike and } \\
\text { UK 'Black Wednesday' }\end{array}$ & Santer & Codecision introduced (1992) & Maastricht Treaty \\
& Commission & and extended (1997) & (1992) and ECB (1998) \\
\hline 2007-12: US subprime & European & Empowered national & EMU decision \\
mortgage and & Stability & parliaments (Lisbon Treaty, & making reforms \\
Eurozone crisis & Mechanism & $2012-)$ \\
\hline
\end{tabular}

show them here if we coded them as 1 for at least one of the EU countries. Details on historical EU reforms as reported in columns 2 to 4. 
Table 2: Financial crises, economic policies and CBI power

\begin{tabular}{|c|c|c|c|c|c|c|c|c|c|}
\hline \multirow[b]{2}{*}{ 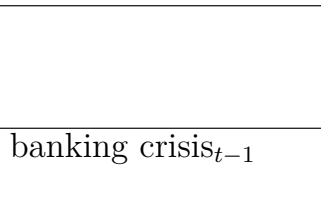 } & \multicolumn{3}{|c|}{$\begin{array}{l}\text { All independent states } \\
\text { (excluding EMU years) } \\
1950-2010\end{array}$} & \multicolumn{3}{|c|}{$\begin{array}{l}\text { All independent states } \\
\text { (excluding EMU states) } \\
\text { 1993-2010 }\end{array}$} & \multicolumn{3}{|c|}{$\begin{array}{c}\text { EMU states } \\
\text { 1993-2010 }\end{array}$} \\
\hline & $\begin{array}{c}6.31 \\
(3.97)\end{array}$ & $\begin{array}{c}6.89 \\
(5.60)\end{array}$ & $\begin{array}{c}8.97 \\
(6.68)\end{array}$ & $\begin{array}{l}13.5^{+} \\
(7.21)\end{array}$ & $\begin{array}{c}14.6 \\
(9.06)\end{array}$ & $\begin{array}{l}15.4^{+} \\
(9.53)\end{array}$ & $\begin{array}{c}0.19 \\
(0.56)\end{array}$ & $\begin{array}{l}-0.13 \\
(0.60)\end{array}$ & $\begin{array}{c}0.65 \\
(1.24)\end{array}$ \\
\hline high debt $t_{t-1}$ & & $\begin{array}{c}0.65 \\
(0.48)\end{array}$ & $\begin{array}{c}0.18 \\
(0.70)\end{array}$ & & $\begin{array}{c}0.12 \\
(1.45)\end{array}$ & $\begin{array}{l}-0.99 \\
(2.05)\end{array}$ & & $\begin{array}{l}2.13^{* *} \\
(0.79)\end{array}$ & $\begin{array}{c}1.45 \\
(1.55)\end{array}$ \\
\hline $\begin{array}{l}\text { banking crisis } \\
\text { high }_{t-1}\end{array}$ & & $\begin{array}{l}-1.04 \\
(7.94)\end{array}$ & $\begin{array}{l}-1.04 \\
(9.62)\end{array}$ & & $\begin{array}{l}-2.34 \\
(14.5)\end{array}$ & $\begin{array}{c}6.31 \\
(15.7)\end{array}$ & & $\begin{array}{c}0 \\
(0.00)\end{array}$ & $\begin{array}{c}0 \\
(0.00)\end{array}$ \\
\hline inflation $_{t-1}$ & & & $\begin{array}{c}0.012 \\
(0.015)\end{array}$ & & & $\begin{array}{c}0.003 \\
(0.013)\end{array}$ & & & $\begin{array}{l}-0.18 \\
(0.13)\end{array}$ \\
\hline government ideology & & & $\begin{array}{c}0.11 \\
(0.28)\end{array}$ & & & $\begin{array}{c}0.22 \\
(0.56)\end{array}$ & & & $\begin{array}{c}0.49 \\
(0.86)\end{array}$ \\
\hline constant & $\begin{array}{l}-0.42 \\
(0.85)\end{array}$ & $\begin{array}{l}-0.73 \\
(0.75)\end{array}$ & $\begin{array}{l}-2.02 \\
(2.37)\end{array}$ & $\begin{array}{l}-0.36 \\
(1.62)\end{array}$ & $\begin{array}{l}3.72^{+} \\
(2.13)\end{array}$ & $\begin{array}{c}5.04 \\
(3.57)\end{array}$ & $\begin{array}{l}-0.76 \\
(0.61)\end{array}$ & $\begin{array}{c}-2.88^{* *} \\
(0.57)\end{array}$ & $\begin{array}{c}16.5 \\
(13.9)\end{array}$ \\
\hline $\mathrm{N}$ & 904 & 793 & 390 & 226 & 220 & 195 & 199 & 199 & 189 \\
\hline Countries & 25 & 25 & 25 & 15 & 15 & 15 & 15 & 15 & 13 \\
\hline$R^{2}$ within & 0.14 & 0.14 & 0.16 & 0.17 & 0.17 & 0.19 & 0.18 & 0.18 & 0.19 \\
\hline$R^{2}$ & 0.17 & 0.17 & 0.19 & 0.19 & 0.19 & 0.21 & 0.19 & 0.19 & 0.21 \\
\hline
\end{tabular}

SE clustered on countries in parentheses. Country and time fixed effects not reported.

Pooled OLS regressions. Dependent variable is Change in CBI.

${ }^{+} p<0.1,{ }^{*} p<0.05,{ }^{* *} p<0.01$ 
Table 3: Financial crises, economic policies and parliaments' power

\begin{tabular}{|c|c|c|c|c|c|c|c|c|c|}
\hline \multirow[b]{2}{*}{ 1.startsysbankclag1 } & \multicolumn{3}{|c|}{$\begin{array}{c}\text { All independent states } \\
\text { (excluding EMU years) } \\
1950-2010\end{array}$} & \multicolumn{3}{|c|}{$\begin{array}{c}\text { All independent states } \\
\text { (excluding EMU states) } \\
1993-2010\end{array}$} & \multicolumn{3}{|c|}{ EMU states } \\
\hline & $\begin{array}{l}-0.043^{*} \\
(0.018)\end{array}$ & $\begin{array}{c}-0.064^{* *} \\
(0.021)\end{array}$ & $\begin{array}{c}-0.092^{* *} \\
(0.020)\end{array}$ & $\begin{array}{l}-0.044 \\
(0.027)\end{array}$ & $\begin{array}{c}-0.084^{* *} \\
(0.017)\end{array}$ & $\begin{array}{c}-0.089^{* *} \\
(0.025)\end{array}$ & $\begin{array}{l}-0.022 \\
(0.035)\end{array}$ & $\begin{array}{l}-0.026 \\
(0.036)\end{array}$ & $\begin{array}{l}-0.048 \\
(0.047)\end{array}$ \\
\hline 1.ldebt_di & & $\begin{array}{l}-0.004 \\
(0.026)\end{array}$ & $\begin{array}{c}0.009 \\
(0.037)\end{array}$ & & $\begin{array}{l}-0.016 \\
(0.088)\end{array}$ & $\begin{array}{c}0.032 \\
(0.091)\end{array}$ & & $\begin{array}{c}0.021 \\
(0.051)\end{array}$ & $\begin{array}{c}0.032 \\
(0.044)\end{array}$ \\
\hline banking $\operatorname{crisis}_{t-1} *$ & & $\begin{array}{c}0.041 \\
(0.033)\end{array}$ & $\begin{array}{c}0.076^{*} \\
(0.032)\end{array}$ & & $\begin{array}{l}0.091^{*} \\
(0.041)\end{array}$ & $\begin{array}{l}0.110^{*} \\
(0.055)\end{array}$ & & $\begin{array}{c}0 \\
(0.00)\end{array}$ & $\begin{array}{c}0 \\
(0.00)\end{array}$ \\
\hline inflation $_{t-1}$ & & & $\begin{array}{c}0.001 \\
(0.000)\end{array}$ & & & $\begin{array}{l}0.001^{+} \\
(0.001)\end{array}$ & & & $\begin{array}{c}0.003 \\
(0.002)\end{array}$ \\
\hline government ideology & & & $\begin{array}{c}-0.001 \\
(0.005)\end{array}$ & & & $\begin{array}{c}0.001 \\
(0.009)\end{array}$ & & & $\begin{array}{l}-0.007 \\
(0.011)\end{array}$ \\
\hline constant & $\begin{array}{c}-0.080^{* *} \\
(0.020)\end{array}$ & $\begin{array}{c}-0.075^{* *} \\
(0.029)\end{array}$ & $\begin{array}{c}-0.11 \\
(0.073)\end{array}$ & $\begin{array}{c}0.025 \\
(0.023)\end{array}$ & $\begin{array}{l}-0.044 \\
(0.087)\end{array}$ & $\begin{array}{c}0.01 \\
(0.00)\end{array}$ & $\begin{array}{l}0.035^{+} \\
(0.018)\end{array}$ & $\begin{array}{c}0.014 \\
(0.056)\end{array}$ & $\begin{array}{l}-0.38 \\
(0.31)\end{array}$ \\
\hline $\mathrm{N}$ & 501 & 491 & 313 & 191 & 188 & 168 & 199 & 199 & 189 \\
\hline Countries & 23 & 23 & 23 & 14 & 14 & 14 & 15 & 15 & 13 \\
\hline$R^{2}$ within & 0.35 & 0.38 & 0.42 & 0.39 & 0.43 & 0.44 & 0.16 & 0.16 & 0.18 \\
\hline$R^{2}$ & 0.38 & 0.41 & 0.45 & 0.41 & 0.44 & 0.46 & 0.19 & 0.19 & 0.20 \\
\hline
\end{tabular}

SE clustered on countries in parentheses. Country and time fixed effects not reported.

Pooled OLS regressions. Dependent variable is Change in Oversight Institutions.

${ }^{+} p<0.1,{ }^{*} p<0.05,{ }^{* *} p<0.01$ 


\section{Online Appendix}

\section{Smoke with Fire: Financial Crises, Institutional Reform, and the Future of EU Democracy}

1. Appendix Figures

- Descriptive Plots

- Marginal Effect Plots

2. Appendix Tables

- Robustness Tests

3. Supplementary Material

- Global Cross-National Analyses 


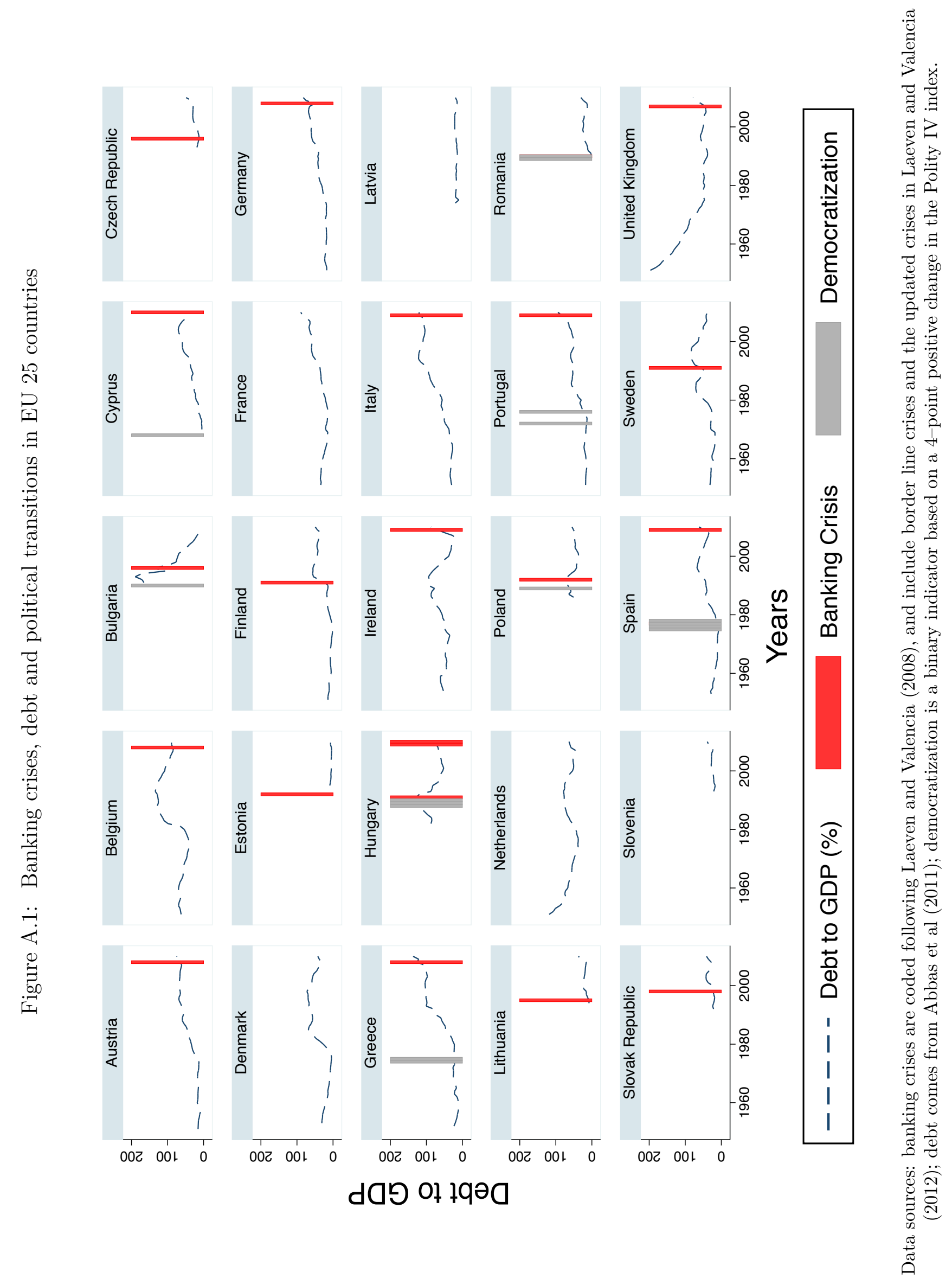



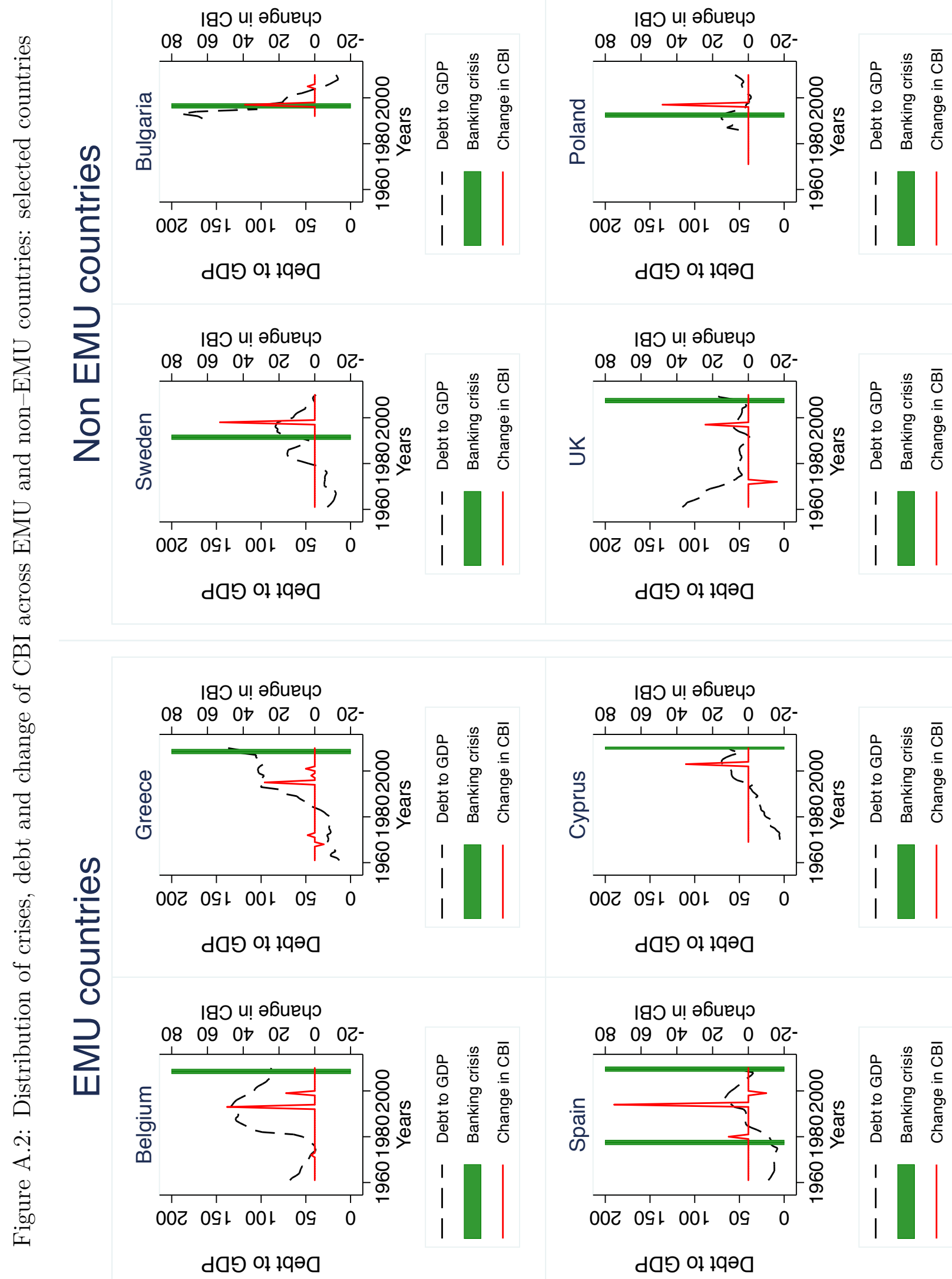

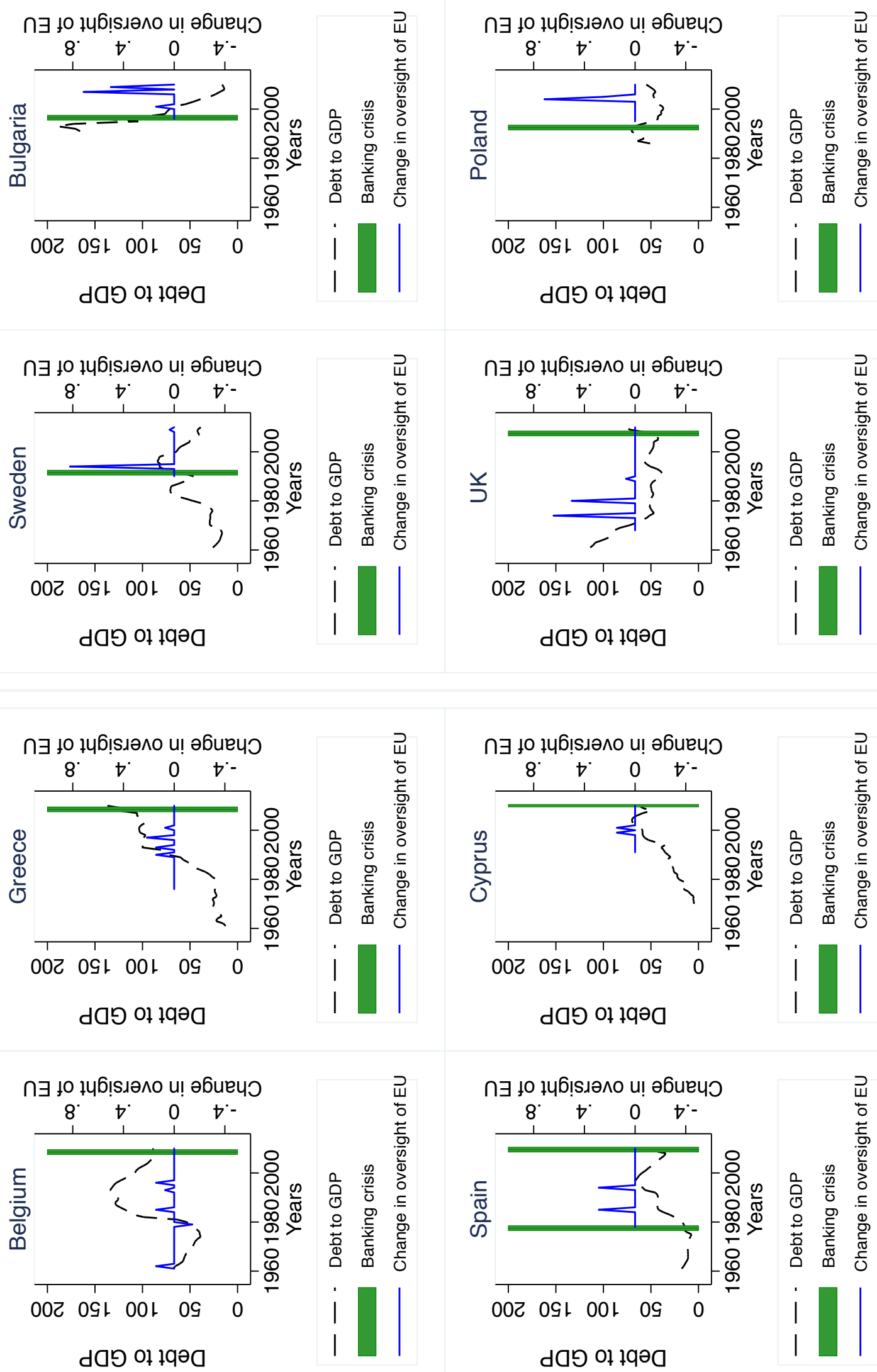
Figure A.4: Marginal effects
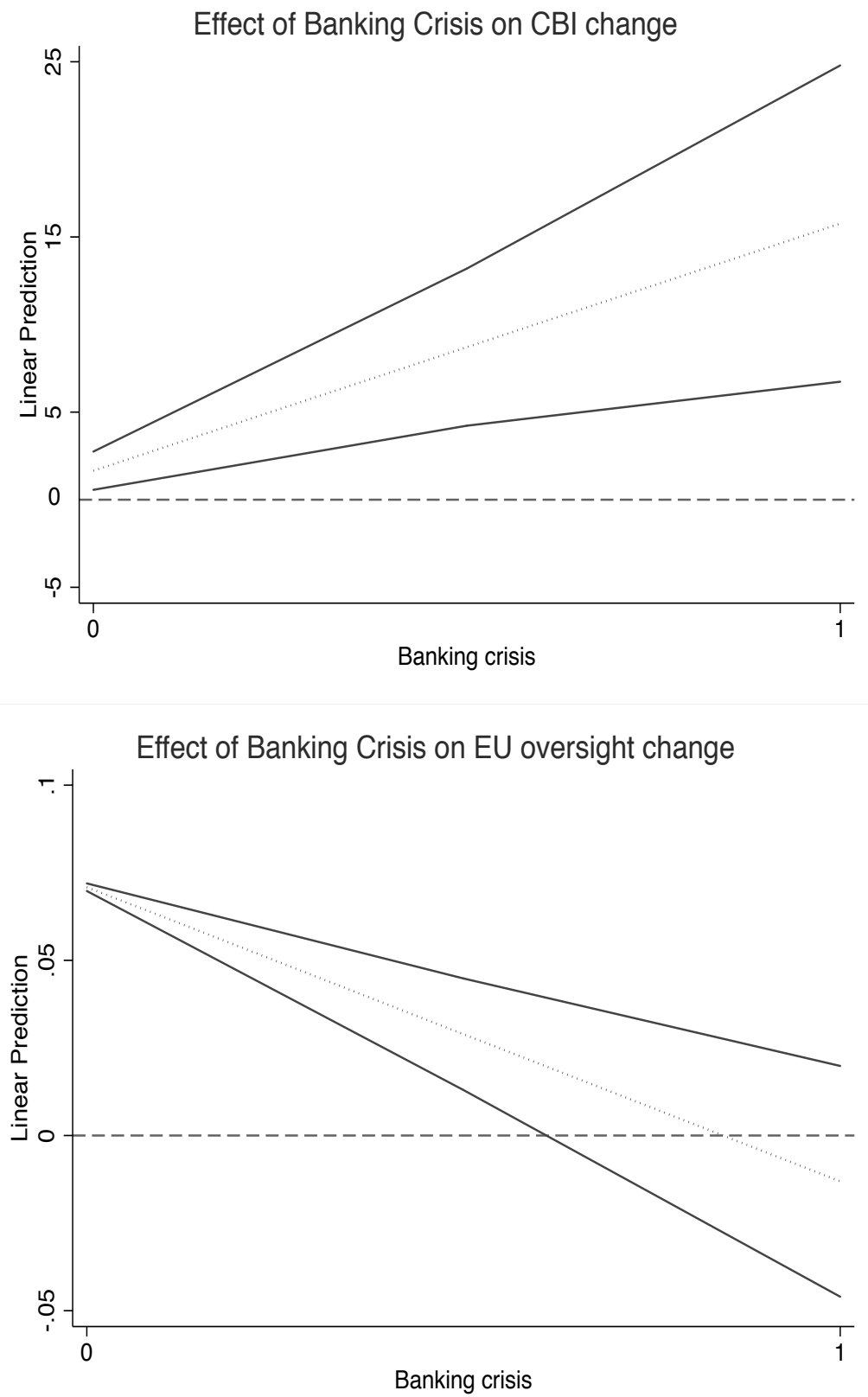

Plots are based on full models with covariates. Dashed line indicate the zero line. Solid lines indicate the $95 \%$ confidence intervals. 
Figure A.5: Marginal effects of crises on outcomes of interest
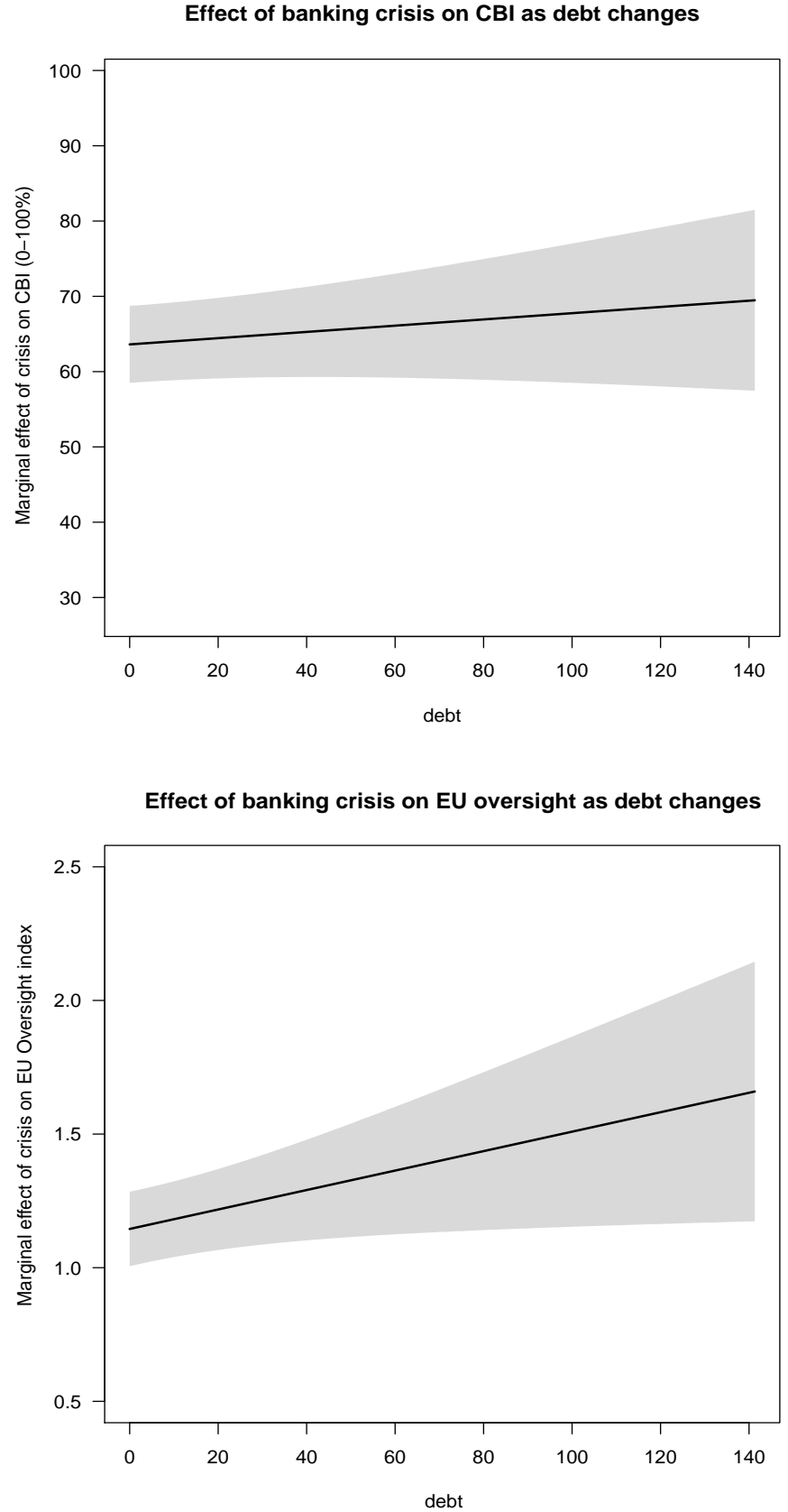

Plots are based on full models with covariates. Grey area indicates the $95 \%$ confidence intervals. 
Table A.1: Financial crises and CBI change: additional controls

\begin{tabular}{|c|c|c|c|c|c|c|}
\hline \multirow{2}{*}{ banking crisis ${ }_{t-1}$} & \multicolumn{2}{|c|}{$\begin{array}{l}\text { Monetarily independent states } \\
\text { (excluding EMU years) } \\
\text { 1950-2010 }\end{array}$} & \multicolumn{2}{|c|}{$\begin{array}{l}\text { Monetarily independent states } \\
\text { (excluding EMU states) } \\
\text { 1993-2010 }\end{array}$} & \multicolumn{2}{|c|}{$\begin{array}{l}\text { EMU states } \\
1993-2010\end{array}$} \\
\hline & $\begin{array}{c}(1) \\
7.62^{+} \\
(4.51)\end{array}$ & $\begin{array}{c}(2) \\
9.25 \\
(6.46)\end{array}$ & $\begin{array}{c}(3) \\
19.8^{*} \\
(9.53)\end{array}$ & $\begin{array}{c}(4) \\
15.9^{+} \\
(9.76)\end{array}$ & $\begin{array}{c}(5) \\
0.01 \\
(0.00)\end{array}$ & $\begin{array}{c}(6) \\
0.01 \\
(0.00)\end{array}$ \\
\hline high debt ${ }_{t-1}$ & & $\begin{array}{c}0.49 \\
(0.60)\end{array}$ & & $\begin{array}{l}5.32^{+} \\
(2.88)\end{array}$ & & $\begin{array}{c}56.4 \\
(51.29)\end{array}$ \\
\hline $\begin{array}{l}\text { banking } \text { crisis }_{t-1}{ }^{*} \\
\text { high debt }_{t-1}\end{array}$ & & $\begin{array}{l}-1.09 \\
(9.32)\end{array}$ & & $\begin{array}{c}18.3 \\
(11.3)\end{array}$ & & $\begin{array}{c}0.01 \\
(0.00)\end{array}$ \\
\hline inflation $_{t-1}$ & & $\begin{array}{l}-0.030 \\
(0.066)\end{array}$ & & $\begin{array}{l}-0.014 \\
(0.14)\end{array}$ & & $\begin{array}{c}-5.87^{* *} \\
(1.97)\end{array}$ \\
\hline government ideology & & $\begin{array}{c}0.20 \\
(0.33)\end{array}$ & & $\begin{array}{c}0.79 \\
(1.43)\end{array}$ & & $\begin{array}{c}0.48 \\
(1.84)\end{array}$ \\
\hline GDP p.c.t-t & $\begin{array}{l}-0.26 \\
(1.35)\end{array}$ & $\begin{array}{l}-5.04 \\
(4.31)\end{array}$ & $\begin{array}{l}-18.0 \\
(11.8)\end{array}$ & $\begin{array}{l}-12.3 \\
(18.5)\end{array}$ & $\begin{array}{c}28.5 \\
(34.7)\end{array}$ & $\begin{array}{l}58.3^{*} \\
(29.0)\end{array}$ \\
\hline trade openness $_{t-1}$ & $\begin{array}{l}2.89^{*} \\
(1.43)\end{array}$ & $\begin{array}{l}8.37^{+} \\
(4.71)\end{array}$ & $\begin{array}{c}0.33 \\
(8.93)\end{array}$ & $\begin{array}{c}0.28 \\
(10.5)\end{array}$ & $\begin{array}{l}-32.3 \\
(77.7)\end{array}$ & $\begin{array}{l}-14.0 \\
(38.5)\end{array}$ \\
\hline constant & $\begin{array}{l}-9.32 \\
(13.4)\end{array}$ & $\begin{array}{c}17.1 \\
(53.1)\end{array}$ & $\begin{array}{c}0 \\
(0.00)\end{array}$ & $\begin{array}{c}0 \\
(0.00)\end{array}$ & $\begin{array}{l}-142.7 \\
(551.4)\end{array}$ & $\begin{array}{c}0 \\
(0.00)\end{array}$ \\
\hline $\mathrm{N}$ & 746 & 279 & 91 & 85 & 73 & 72 \\
\hline Countries & 24 & 24 & 14 & 14 & 11 & 11 \\
\hline$R^{2}$ within & 0.17 & 0.22 & 0.27 & 0.31 & 0.15 & 0.40 \\
\hline$R^{2}$ & 0.20 & 0.27 & 0.32 & 0.36 & 0.19 & 0.42 \\
\hline
\end{tabular}

SE clustered on countries in parentheses. Country and time fixed effects not reported.

${ }^{+} p<0.1,{ }^{*} p<0.05,{ }^{* *} p<0.01$ 
Table A.2: Financial crises and change of oversight institutions: additional controls

\begin{tabular}{|c|c|c|c|c|c|c|}
\hline & \multicolumn{2}{|c|}{$\begin{array}{l}\text { Monetarily independent states } \\
\text { (excluding EMU years) } \\
1950-2010\end{array}$} & \multicolumn{2}{|c|}{$\begin{array}{c}\text { Monetarily independent states } \\
\text { (excluding EMU states) } \\
1993-2010\end{array}$} & \multicolumn{2}{|c|}{$\begin{array}{l}\text { EMU states } \\
\text { 1993-2010 }\end{array}$} \\
\hline & $(1)$ & $(2)$ & $(3)$ & $(4)$ & $(5)$ & $(6)$ \\
\hline banking crisis $_{t-1}$ & $\begin{array}{l}-0.065^{*} \\
(0.027)\end{array}$ & $\begin{array}{l}-0.094^{* *} \\
(0.033)\end{array}$ & $\begin{array}{l}-0.067 \\
(0.059)\end{array}$ & $\begin{array}{l}-0.073 \\
(0.051)\end{array}$ & $\begin{array}{c}0 \\
(0.00)\end{array}$ & $\begin{array}{c}0 \\
(0.00)\end{array}$ \\
\hline high debt ${ }_{t-1}$ & & $\begin{array}{l}-0.010 \\
(0.020)\end{array}$ & & $\begin{array}{l}-0.050 \\
(0.045)\end{array}$ & & $\begin{array}{l}-11.4 \\
(12.1)\end{array}$ \\
\hline $\begin{array}{l}\text { banking } \text { crisis }_{t-1} * \\
\text { high debt }_{t-1}\end{array}$ & & $\begin{array}{c}0.028 \\
(0.031)\end{array}$ & & $\begin{array}{c}0.12 \\
(0.091)\end{array}$ & & $\begin{array}{c}0 \\
(0.00)\end{array}$ \\
\hline inflation $_{t-1}$ & & $\begin{array}{l}-0.000 \\
(0.000)\end{array}$ & & $\begin{array}{c}0.001 \\
(0.001)\end{array}$ & & $\begin{array}{c}0.047 \\
(0.036)\end{array}$ \\
\hline government ideology & & $\begin{array}{l}-0.004 \\
(0.006)\end{array}$ & & $\begin{array}{l}-0.005 \\
(0.027)\end{array}$ & & $\begin{array}{l}-0.001 \\
(0.025)\end{array}$ \\
\hline GDP p.c. ${ }_{t-1}$ & $\begin{array}{l}-0.11 \\
(0.11)\end{array}$ & $\begin{array}{l}-0.13 \\
(0.12)\end{array}$ & $\begin{array}{c}0.35 \\
(0.58)\end{array}$ & $\begin{array}{c}0.36 \\
(0.53)\end{array}$ & $\begin{array}{c}0.45 \\
(0.42)\end{array}$ & $\begin{array}{c}0.35 \\
(0.49)\end{array}$ \\
\hline trade openness ${ }_{t-1}$ & $\begin{array}{c}0.058 \\
(0.048)\end{array}$ & $\begin{array}{c}0.050 \\
(0.079)\end{array}$ & $\begin{array}{l}-0.054 \\
(0.29)\end{array}$ & $\begin{array}{r}-0.068 \\
(0.31)\end{array}$ & $\begin{array}{c}0.67 \\
(1.44)\end{array}$ & $\begin{array}{c}0.71 \\
(1.20)\end{array}$ \\
\hline constant & $\begin{array}{c}0.81 \\
(1.10)\end{array}$ & $\begin{array}{l}1.07 \\
(1.12)\end{array}$ & $\begin{array}{c}0 \\
(0.00)\end{array}$ & $\begin{array}{c}0 \\
(0.00)\end{array}$ & $\begin{array}{l}-7.57 \\
(10.5)\end{array}$ & $\begin{array}{c}0 \\
(0.00)\end{array}$ \\
\hline $\mathrm{N}$ & 366 & 212 & 68 & 67 & 73 & 72 \\
\hline Countries & 22 & 22 & 13 & 13 & 11 & 11 \\
\hline$R^{2}$ within & 0.20 & 0.25 & 0.32 & 0.34 & 0.21 & 0.29 \\
\hline$R^{2}$ & 0.24 & 0.30 & 0.38 & 0.40 & 0.28 & 0.35 \\
\hline
\end{tabular}

SE clustered on countries in parentheses. Country and time fixed effects not reported.

${ }^{+} p<0.1,{ }^{*} p<0.05,{ }^{* *} p<0.01$ 
Table A.3: Financial Crises and Change in CBI: subsamples

\begin{tabular}{|c|c|c|c|c|c|c|c|c|c|}
\hline & \multicolumn{3}{|c|}{$\begin{array}{c}\text { All states } \\
\text { (EMU and non-EMU included) } \\
1950-2010\end{array}$} & \multicolumn{3}{|c|}{$\begin{array}{c}\text { All states } \\
\text { (EMU and non-EMU included) } \\
1993-2010\end{array}$} & \multicolumn{3}{|c|}{$\begin{array}{c}\text { EMU states } \\
\text { (all accession years) } \\
1990-2010\end{array}$} \\
\hline & $(1)$ & $(2)$ & $(3)$ & $(4)$ & $(5)$ & $(6)$ & $(7)$ & $(8)$ & (9) \\
\hline banking crisis $_{t-1}$ & $\begin{array}{c}3.66 \\
(2.66)\end{array}$ & $\begin{array}{c}6.41 \\
(5.28)\end{array}$ & $\begin{array}{c}8.22 \\
(6.16)\end{array}$ & $\begin{array}{c}5.92 \\
(3.65)\end{array}$ & $\begin{array}{l}13.6 \\
(9.07)\end{array}$ & $\begin{array}{c}14.3 \\
(8.75)\end{array}$ & $\begin{array}{c}0.51 \\
(0.39)\end{array}$ & $\begin{array}{c}0.95 \\
(0.77)\end{array}$ & $\begin{array}{c}1.36 \\
(0.91)\end{array}$ \\
\hline high debt ${ }_{t-1}$ & & $\begin{array}{c}0.14 \\
(0.65)\end{array}$ & $\begin{array}{l}-0.19 \\
(0.99)\end{array}$ & & $\begin{array}{l}1.77^{+} \\
(0.98)\end{array}$ & $\begin{array}{c}1.48 \\
(1.07)\end{array}$ & & $\begin{array}{l}-3.22 \\
(5.23)\end{array}$ & $\begin{array}{l}-3.87 \\
(5.60)\end{array}$ \\
\hline $\begin{array}{l}\text { banking crisis } \\
\text { high debt }_{t-1}\end{array}$ & & $\begin{array}{l}-4.05 \\
(6.11)\end{array}$ & $\begin{array}{l}-5.20 \\
(7.19)\end{array}$ & & $\begin{array}{l}-10.3 \\
(9.96)\end{array}$ & $\begin{array}{l}-10.3 \\
(10.1)\end{array}$ & & $\begin{array}{c}0 \\
(0.00)\end{array}$ & $\begin{array}{c}0 \\
(0.00)\end{array}$ \\
\hline inflation $_{t-1}$ & & & $\begin{array}{c}0.020 \\
(0.015)\end{array}$ & & & $\begin{array}{c}0.011 \\
(0.018)\end{array}$ & & & $\begin{array}{c}-0.12 \\
(0.13)\end{array}$ \\
\hline government ideology & & & $\begin{array}{c}0.29 \\
(0.27)\end{array}$ & & & $\begin{array}{c}0.53 \\
(0.45)\end{array}$ & & & $\begin{array}{c}0.48 \\
(0.72)\end{array}$ \\
\hline constant & $\begin{array}{l}-0.84 \\
(0.59)\end{array}$ & $\begin{array}{l}-0.71 \\
(0.77)\end{array}$ & $\begin{array}{l}-4.55^{*} \\
(2.12)\end{array}$ & $\begin{array}{r}-1.75^{+} \\
(0.96)\end{array}$ & $\begin{array}{c}-2.89^{* *} \\
(0.99)\end{array}$ & $\begin{array}{c}-5.39^{+} \\
(2.83)\end{array}$ & $\begin{array}{c}-1.45^{* *} \\
(0.46)\end{array}$ & $\begin{array}{c}1.79 \\
(5.26)\end{array}$ & $\begin{array}{c}15.3 \\
(17.0)\end{array}$ \\
\hline $\mathrm{N}$ & 1113 & 1002 & 589 & 425 & 419 & 384 & 209 & 209 & 199 \\
\hline Countries & 25 & 25 & 25 & 25 & 25 & 25 & 15 & 15 & 13 \\
\hline$R^{2}$ within & 0.10 & 0.10 & 0.093 & 0.084 & 0.094 & 0.099 & 0.17 & 0.17 & 0.18 \\
\hline$R^{2}$ & 0.11 & 0.11 & 0.10 & 0.10 & 0.11 & 0.12 & 0.17 & 0.18 & 0.18 \\
\hline
\end{tabular}

SE clustered on countries in parentheses. Country and time fixed effects not reported.

$+p<0.1,{ }^{*} p<0.05,{ }^{* *} p<0.01$ 
Table A.4: Financial Crises and Change in Oversight Institutions: subsamples

\begin{tabular}{|c|c|c|c|c|c|c|c|c|c|}
\hline & \multicolumn{3}{|c|}{$\begin{array}{c}\text { All states } \\
\text { (EMU and non-EMU included) } \\
1950-2010\end{array}$} & \multicolumn{3}{|c|}{$\begin{array}{c}\text { All states } \\
\text { (EMU and non-EMU included) } \\
1993-2010\end{array}$} & \multicolumn{3}{|c|}{$\begin{array}{c}\text { EMU states } \\
\text { (all accession years) } \\
1990-2010\end{array}$} \\
\hline & $(1)$ & $(2)$ & $(3)$ & $(4)$ & $(5)$ & $(6)$ & $(7)$ & $(8)$ & $(9)$ \\
\hline banking crisis $_{t-1}$ & $\begin{array}{l}-0.021 \\
(0.015)\end{array}$ & $\begin{array}{c}-0.068^{* *} \\
(0.024)\end{array}$ & $\begin{array}{l}-0.11^{* *} \\
(0.018)\end{array}$ & $\begin{array}{l}-0.021 \\
(0.017)\end{array}$ & $\begin{array}{c}-0.092^{* *} \\
(0.015)\end{array}$ & $\begin{array}{c}-0.099^{* *} \\
(0.021)\end{array}$ & $\begin{array}{l}-0.025 \\
(0.035)\end{array}$ & $\begin{array}{l}-0.028 \\
(0.036)\end{array}$ & $\begin{array}{l}-0.052 \\
(0.049)\end{array}$ \\
\hline high debt de-1 & & $\begin{array}{c}0.010 \\
(0.020)\end{array}$ & $\begin{array}{c}0.021 \\
(0.025)\end{array}$ & & $\begin{array}{c}0.024 \\
(0.053)\end{array}$ & $\begin{array}{c}0.057 \\
(0.050)\end{array}$ & & $\begin{array}{c}0.022 \\
(0.058)\end{array}$ & $\begin{array}{c}0.038 \\
(0.055)\end{array}$ \\
\hline $\begin{array}{l}\text { banking crisis }{ }_{t-1} * \\
\text { high debt }_{t-1}\end{array}$ & & $\begin{array}{l}0.062^{+} \\
(0.033)\end{array}$ & $\begin{array}{l}0.089^{* *} \\
(0.028)\end{array}$ & & $\begin{array}{l}0.091^{* *} \\
(0.029)\end{array}$ & $\begin{array}{l}0.084^{*} \\
(0.039)\end{array}$ & & $\begin{array}{c}0.00 \\
(0.00)\end{array}$ & $\begin{array}{c}0.00 \\
(0.00)\end{array}$ \\
\hline inflation $_{t-1}$ & & & $\begin{array}{l}0.001^{*} \\
(0.000)\end{array}$ & & & $\begin{array}{l}0.002^{* *} \\
(0.001)\end{array}$ & & & $\begin{array}{c}0.004 \\
(0.002)\end{array}$ \\
\hline government ideology & & & $\begin{array}{l}-0.003 \\
(0.004)\end{array}$ & & & $\begin{array}{l}-0.003 \\
(0.007)\end{array}$ & & & $\begin{array}{l}-0.011 \\
(0.010)\end{array}$ \\
\hline constant & $\begin{array}{l}-0.003 \\
(0.009) \\
\end{array}$ & $\begin{array}{l}-0.018 \\
(0.025) \\
\end{array}$ & $\begin{array}{l}-0.097 \\
(0.064)\end{array}$ & $\begin{array}{c}0.007 \\
(0.010) \\
\end{array}$ & $\begin{array}{l}-0.022 \\
(0.055) \\
\end{array}$ & $\begin{array}{l}-0.22^{*} \\
(0.091) \\
\end{array}$ & $\begin{array}{l}0.031^{+} \\
(0.018) \\
\end{array}$ & $\begin{array}{c}0.009 \\
(0.065) \\
\end{array}$ & $\begin{array}{l}-0.41 \\
(0.31) \\
\end{array}$ \\
\hline Obs & 710 & 700 & 512 & 390 & 387 & 357 & 209 & 209 & 199 \\
\hline Countries & 24 & 24 & 24 & 24 & 24 & 24 & 15 & 15 & 13 \\
\hline$R^{2}$ within & 0.18 & 0.19 & 0.20 & 0.19 & 0.20 & 0.21 & 0.15 & 0.15 & 0.17 \\
\hline$R^{2}$ & 0.21 & 0.21 & 0.23 & 0.22 & 0.22 & 0.24 & 0.17 & 0.17 & 0.19 \\
\hline
\end{tabular}

SE clustered on countries in parentheses. Country and time fixed effects not reported.

$+p<0.1,{ }^{*} p<0.05,{ }^{* *} p<0.01$ 
Table A.5: Financial Crises and Change in CBI: Population-averaged Estimation

\begin{tabular}{|c|c|c|c|c|c|c|}
\hline & \multicolumn{3}{|c|}{$\begin{array}{c}\text { All states } \\
\text { (EMU and non-EMU included) } \\
1950-2010\end{array}$} & \multicolumn{3}{|c|}{$\begin{array}{c}\text { Monetarily independent states } \\
\text { (excluding EMU) } \\
1993-2010\end{array}$} \\
\hline & (1) & $(2)$ & $(3)$ & $(4)$ & $(5)$ & (6) \\
\hline banking crisis $_{t-1}$ & $\begin{array}{c}3.552 \\
(2.542)\end{array}$ & $\begin{array}{l}7.356 \\
(5.035)\end{array}$ & $\begin{array}{l}8.240 \\
(5.716)\end{array}$ & $\begin{array}{l}12.51^{+} \\
(6.841)\end{array}$ & $\begin{array}{l}14.11^{+} \\
(7.808)\end{array}$ & $\begin{array}{l}13.67^{+} \\
(7.546)\end{array}$ \\
\hline high debt $t_{t-1}$ & & $\begin{array}{l}0.950^{* *} \\
(0.363)\end{array}$ & $\begin{array}{l}0.550 \\
(0.557)\end{array}$ & & $\begin{array}{l}1.082 \\
(0.797)\end{array}$ & $\begin{array}{c}0.654 \\
(0.800)\end{array}$ \\
\hline $\begin{array}{l}\text { banking crisis } \\
\text { high }_{t-1}\end{array}$ & & $\begin{array}{l}-5.831 \\
(5.688)\end{array}$ & $\begin{array}{l}-6.907 \\
(6.522)\end{array}$ & & $\begin{array}{l}-3.416 \\
(13.55)\end{array}$ & $\begin{array}{l}3.006 \\
(16.07)\end{array}$ \\
\hline inflation $_{t-1}$ & & & $\begin{array}{c}0.002 \\
(0.006)\end{array}$ & & & $\begin{array}{c}-0.011 \\
(0.013)\end{array}$ \\
\hline government ideology & & & $\begin{array}{l}0.316^{+} \\
(0.161)\end{array}$ & & & $\begin{array}{c}0.333 \\
(0.346)\end{array}$ \\
\hline constant & $\begin{array}{c}0.698^{* *} \\
(0.0935)\end{array}$ & $\begin{array}{c}0.310 \\
(0.261)\end{array}$ & $\begin{array}{l}0.0227 \\
(0.844)\end{array}$ & $\begin{array}{l}1.654^{* *} \\
(0.399)\end{array}$ & $\begin{array}{l}1.225^{*} \\
(0.538)\end{array}$ & $\begin{array}{l}1.718 \\
(1.732)\end{array}$ \\
\hline Obs & 1113 & 1002 & 589 & 226 & 220 & 195 \\
\hline Countries & 25 & 25 & 25 & 15 & 15 & 15 \\
\hline$\chi^{2}$ & 1.952 & 10.36 & 8.677 & 3.345 & 6.409 & 7.101 \\
\hline
\end{tabular}


Table A.6: Financial Crises and Change in Oversight Institutions: Population-averaged Estimation

\begin{tabular}{|c|c|c|c|c|c|c|}
\hline & \multicolumn{3}{|c|}{$\begin{array}{c}\text { All states } \\
\text { (EMU and non-EMU included) } \\
1950-2010\end{array}$} & \multicolumn{3}{|c|}{$\begin{array}{c}\text { Monetarily independent states } \\
\text { (excluding EMU) } \\
\text { 1993-2010 }\end{array}$} \\
\hline & $(1)$ & (2) & $(3)$ & $(4)$ & (5) & (6) \\
\hline banking crisis $_{t-1}$ & $\begin{array}{c}-0.036^{* *} \\
(0.005)\end{array}$ & $\begin{array}{c}-0.048^{* *} \\
(0.009)\end{array}$ & $\begin{array}{l}-0.052^{* *} \\
(0.012)\end{array}$ & $\begin{array}{l}-0.070^{* *} \\
(0.010)\end{array}$ & $\begin{array}{c}-0.085^{* *} \\
(0.014)\end{array}$ & $\begin{array}{l}-0.075^{* *} \\
(0.021)\end{array}$ \\
\hline high debt ${ }_{t-1}$ & & $\begin{array}{c}-0.012 \\
(0.013)\end{array}$ & $\begin{array}{l}-0.018 \\
(0.015)\end{array}$ & & $\begin{array}{c}-0.031 \\
(0.026)\end{array}$ & $\begin{array}{l}-0.024 \\
(0.036)\end{array}$ \\
\hline $\begin{array}{l}\text { banking } \text { crisis }_{t-1} * \\
\text { high debt }_{t-1}\end{array}$ & & $\begin{array}{c}0.005 \\
(0.012)\end{array}$ & $\begin{array}{c}0.004 \\
(0.015)\end{array}$ & & $\begin{array}{c}0.031 \\
(0.026)\end{array}$ & $\begin{array}{c}0.042 \\
(0.035)\end{array}$ \\
\hline government ideology & & & $\begin{array}{l}-0.001 \\
(0.001)\end{array}$ & & & $\begin{array}{l}-0.001 \\
(0.011)\end{array}$ \\
\hline inflation $_{t-1}$ & & & $\begin{array}{l}0.001^{* *} \\
(0.000)\end{array}$ & & & $\begin{array}{c}0.001 \\
(0.001)\end{array}$ \\
\hline constant & $\begin{array}{l}0.036^{* *} \\
(0.005)\end{array}$ & $\begin{array}{l}0.052^{* *} \\
(0.010)\end{array}$ & $\begin{array}{c}0.027 \\
(0.017)\end{array}$ & $\begin{array}{l}0.070^{* *} \\
(0.010)\end{array}$ & $\begin{array}{c}0.08^{* *} \\
(0.014)\end{array}$ & $\begin{array}{c}0.041 \\
(0.063)\end{array}$ \\
\hline Obs & 710 & 460 & 512 & 191 & 188 & 168 \\
\hline Countries & 24 & 24 & 24 & 14 & 14 & 14 \\
\hline$\chi^{2}$ & 51.12 & 51.37 & 58.25 & 47.15 & 72.34 & 71.92 \\
\hline
\end{tabular}


Table A.7: Financial Crises and Change in Oversight Institutions: Alternative Index

\begin{tabular}{|c|c|c|c|c|c|c|c|c|c|}
\hline & \multicolumn{3}{|c|}{$\begin{array}{l}\text { Monetarily independent states } \\
\text { (excluding EMU years) } \\
1950-2010\end{array}$} & \multicolumn{3}{|c|}{$\begin{array}{l}\text { Monetarily independent states } \\
\text { (excluding EMU states) } \\
1993-2010\end{array}$} & \multicolumn{3}{|c|}{$\begin{array}{l}\text { EMU states } \\
1993-2010\end{array}$} \\
\hline & (1) & (2) & (3) & $(4)$ & $(5)$ & $(6)$ & (7) & $(8)$ & $(9)$ \\
\hline banking crisis $_{t-1}$ & $\begin{array}{l}-0.055^{* *} \\
(0.018)\end{array}$ & $\begin{array}{c}-0.093^{* *} \\
(0.031)\end{array}$ & $\begin{array}{c}-0.143^{* *} \\
(0.020)\end{array}$ & $\begin{array}{l}-0.053 \\
(0.040)\end{array}$ & $\begin{aligned}-0.103^{* *} \\
(0.023)\end{aligned}$ & $\begin{array}{c}-0.098^{* *} \\
(0.032)\end{array}$ & $\begin{array}{l}-0.018 \\
(0.029)\end{array}$ & $\begin{array}{l}-0.018 \\
(0.031)\end{array}$ & $\begin{array}{l}-0.048 \\
(0.049)\end{array}$ \\
\hline high debt ${ }_{t-1}$ & & $\begin{array}{c}0.019 \\
(0.035)\end{array}$ & $\begin{array}{c}0.035 \\
(0.049)\end{array}$ & & $\begin{array}{c}0.028 \\
(0.152)\end{array}$ & $\begin{array}{c}0.102 \\
(0.180)\end{array}$ & & $\begin{array}{c}0.001 \\
(0.087)\end{array}$ & $\begin{array}{c}0.018 \\
(0.078)\end{array}$ \\
\hline $\begin{array}{l}\text { banking } \operatorname{crisis}_{t-1} * \\
\text { high debt }_{t-1}\end{array}$ & & $\begin{array}{c}0.020 \\
(0.036)\end{array}$ & $\begin{array}{c}0.035 \\
(0.029)\end{array}$ & & $\begin{array}{l}0.111^{+} \\
(0.057)\end{array}$ & $\begin{array}{c}0.164 \\
(0.122)\end{array}$ & & $\begin{array}{c}0.00 \\
(0.00)\end{array}$ & $\begin{array}{c}0.00 \\
(0.00)\end{array}$ \\
\hline inflation $_{t-1}$ & & & $\begin{array}{l}0.002^{* *} \\
(0.000)\end{array}$ & & & $\begin{array}{l}0.003^{* *} \\
(0.001)\end{array}$ & & & $\begin{array}{c}0.005 \\
(0.003)\end{array}$ \\
\hline government ideology & & & $\begin{array}{c}-0.002 \\
(0.008)\end{array}$ & & & $\begin{array}{c}0.003 \\
(0.020)\end{array}$ & & & $\begin{array}{l}-0.005 \\
(0.016)\end{array}$ \\
\hline constant & $\begin{array}{l}-0.006 \\
(0.015)\end{array}$ & $\begin{array}{c}-0.034 \\
(0.043)\end{array}$ & $\begin{array}{l}-0.229^{*} \\
(0.112)\end{array}$ & $\begin{array}{l}0.063^{+} \\
(0.036)\end{array}$ & $\begin{array}{l}-0.144 \\
(0.160)\end{array}$ & $\begin{array}{c}0 \\
(0.00)\end{array}$ & $\begin{array}{l}0.061^{* *} \\
(0.022)\end{array}$ & $\begin{array}{c}0.060 \\
(0.094)\end{array}$ & $\begin{array}{l}-0.534 \\
(0.461)\end{array}$ \\
\hline Obs & 710 & 700 & 512 & 191 & 188 & 168 & 199 & 199 & 189 \\
\hline Countries & 24 & 24 & 24 & 14 & 14 & 14 & 15 & 15 & 13 \\
\hline$R^{2}$ (within) & 0.175 & 0.182 & 0.187 & 0.389 & 0.424 & 0.429 & 0.138 & 0.138 & 0.152 \\
\hline$R^{2}$ & 0.199 & 0.206 & 0.216 & 0.401 & 0.435 & 0.443 & 0.164 & 0.164 & 0.176 \\
\hline
\end{tabular}

SE clustered on countries in parentheses. Country and time fixed effects not reported.

${ }^{+} p<0.1,{ }^{*} p<0.05,{ }^{* *} p<0.01$ 
Table A.8: Financial Crises and Change in Oversight Institutions: Tobit Models

\begin{tabular}{|c|c|c|c|c|c|c|c|c|c|}
\hline & \multicolumn{3}{|c|}{$\begin{array}{l}\text { Monetarily independent states } \\
\text { (excluding EMU years) } \\
1950-2010\end{array}$} & \multicolumn{3}{|c|}{$\begin{array}{l}\text { Monetarily independent states } \\
\text { (excluding EMU states) } \\
1993-2010\end{array}$} & \multicolumn{3}{|c|}{$\begin{array}{l}\text { EMU states } \\
1993-2010 \\
\end{array}$} \\
\hline banking crisis ${ }_{t-1}$ & $\begin{array}{c}(1) \\
-0.043^{*} \\
(0.014)\end{array}$ & $\begin{array}{c}(2) \\
-0.064^{* *} \\
(0.023)\end{array}$ & $\begin{array}{c}(3) \\
-0.092^{* *} \\
(0.0168)\end{array}$ & $\begin{array}{c}(4) \\
-0.044^{+} \\
(0.025)\end{array}$ & $\begin{array}{c}\frac{(5)}{-0.084^{* *}} \\
(0.015)\end{array}$ & $\begin{array}{c}(6) \\
-0.089^{* *} \\
(0.022)\end{array}$ & $\begin{array}{c}(7) \\
-0.022 \\
(0.032)\end{array}$ & $\begin{array}{c}(8) \\
-0.025 \\
(0.032)\end{array}$ & $\begin{array}{c}(9) \\
-0.048 \\
(0.043)\end{array}$ \\
\hline high debt $t_{t-1}$ & & $\begin{array}{c}0.010 \\
(0.019)\end{array}$ & $\begin{array}{c}0.020 \\
(0.024)\end{array}$ & & $\begin{array}{l}-0.016 \\
(0.080)\end{array}$ & $\begin{array}{c}0.032 \\
(0.081)\end{array}$ & & $\begin{array}{l}0.0210 \\
(0.046)\end{array}$ & $\begin{array}{c}0.032 \\
(0.040)\end{array}$ \\
\hline $\begin{array}{l}\text { banking crisis }{ }_{t-1} * \\
\text { high debt }_{t-1}\end{array}$ & & $\begin{array}{c}0.061^{*} \\
(0.030)\end{array}$ & $\begin{array}{l}0.089^{* *} \\
(0.026)\end{array}$ & & $\begin{array}{l}0.090^{*} \\
(0.037)\end{array}$ & $\begin{array}{l}0.113^{*} \\
(0.048)\end{array}$ & & & \\
\hline inflation $_{t-1}$ & & & $\begin{array}{l}0.001^{*} \\
(0.001)\end{array}$ & & & $\begin{array}{l}0.001^{*} \\
(0.001)\end{array}$ & & & $\begin{array}{c}0.003 \\
(0.002)\end{array}$ \\
\hline government ideology & & & $\begin{array}{l}-0.003 \\
(0.004)\end{array}$ & & & $\begin{array}{c}0.001 \\
(0.008)\end{array}$ & & & $\begin{array}{l}-0.007 \\
(0.009)\end{array}$ \\
\hline constant & $\begin{array}{c}-0.003 \\
(0.00)\end{array}$ & $\begin{array}{c}-0.018 \\
(0.0212)\end{array}$ & $\begin{array}{l}-0.097 \\
(0.061)\end{array}$ & $\begin{array}{c}-0.067^{* *} \\
(0.013)\end{array}$ & $\begin{array}{l}-0.064 \\
(0.067)\end{array}$ & $\begin{array}{c}-0.229^{*} \\
(0.094)\end{array}$ & $\begin{array}{c}0.034^{*} \\
(0.016)\end{array}$ & $\begin{array}{l}0.0135 \\
(0.052)\end{array}$ & $\begin{array}{l}-0.380 \\
(0.284)\end{array}$ \\
\hline$\sigma$ & $\begin{array}{l}0.139^{* *} \\
(0.007)\end{array}$ & $\begin{array}{l}0.139^{* *} \\
(0.007)\end{array}$ & $\begin{array}{l}0.154^{* *} \\
(0.017)\end{array}$ & $\begin{array}{l}0.170^{* *} \\
(0.016)\end{array}$ & $\begin{array}{l}0.166^{* *} \\
(0.017)\end{array}$ & $\begin{array}{l}0.171^{* *} \\
(0.018)\end{array}$ & $\begin{array}{l}0.150^{* *} \\
(0.034) \\
\end{array}$ & $\begin{array}{l}0.150^{* *} \\
(0.034)\end{array}$ & $\begin{array}{l}0.152^{* *} \\
(0.033)\end{array}$ \\
\hline Obs & 710 & 700 & 512 & 191 & 188 & 168 & 199 & 199 & 189 \\
\hline Countries & 24 & 24 & 24 & 14 & 14 & 14 & 15 & 15 & 13 \\
\hline Log-Likelihood & 393.6 & 386.4 & 227.1 & 67.22 & 70.57 & 58.42 & 92.11 & 92.19 & 84.49 \\
\hline
\end{tabular}

SE clustered on countries in parentheses. Country and time fixed effects not reported.

${ }^{+} p<0.1,{ }^{*} p<0.05,{ }^{* *} p<0.01$ 


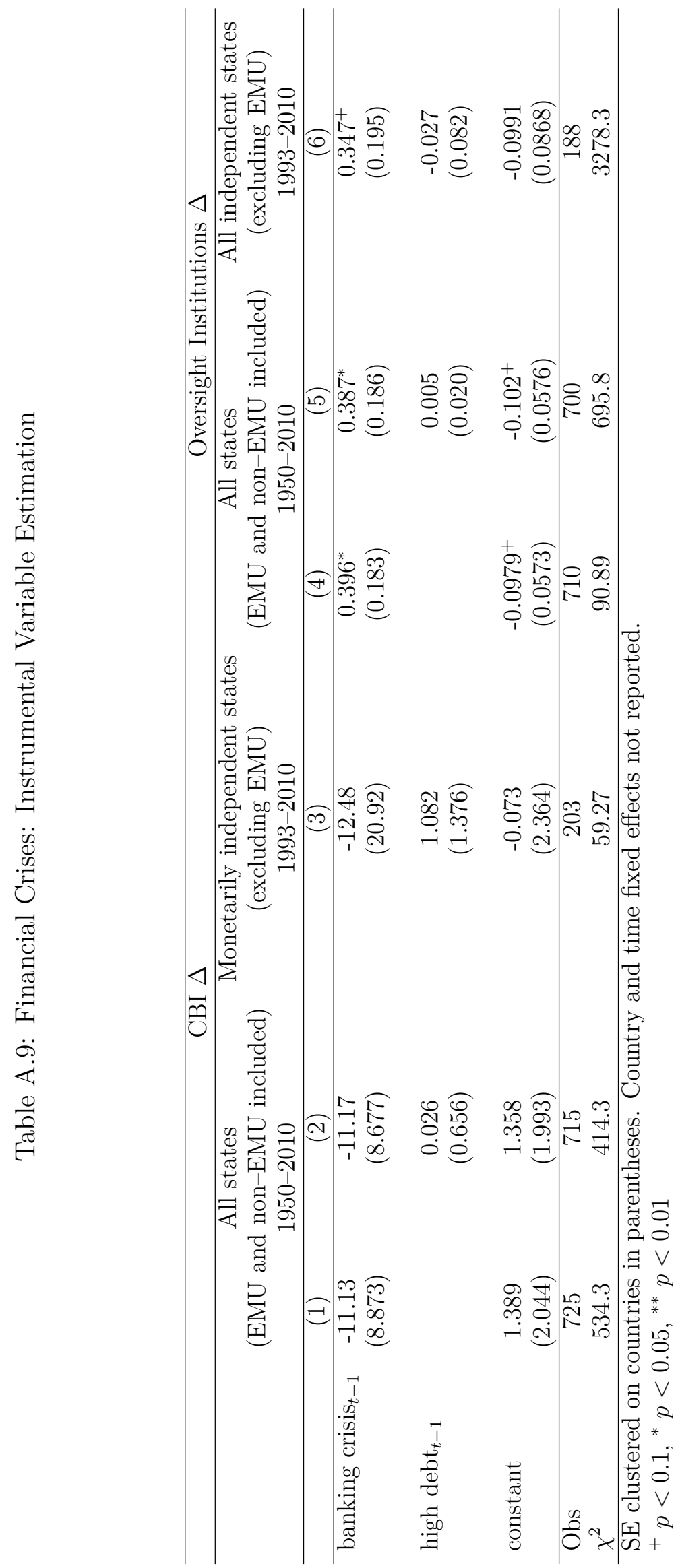


Table A.10: Financial crises and Change in CBI: Currency Crises

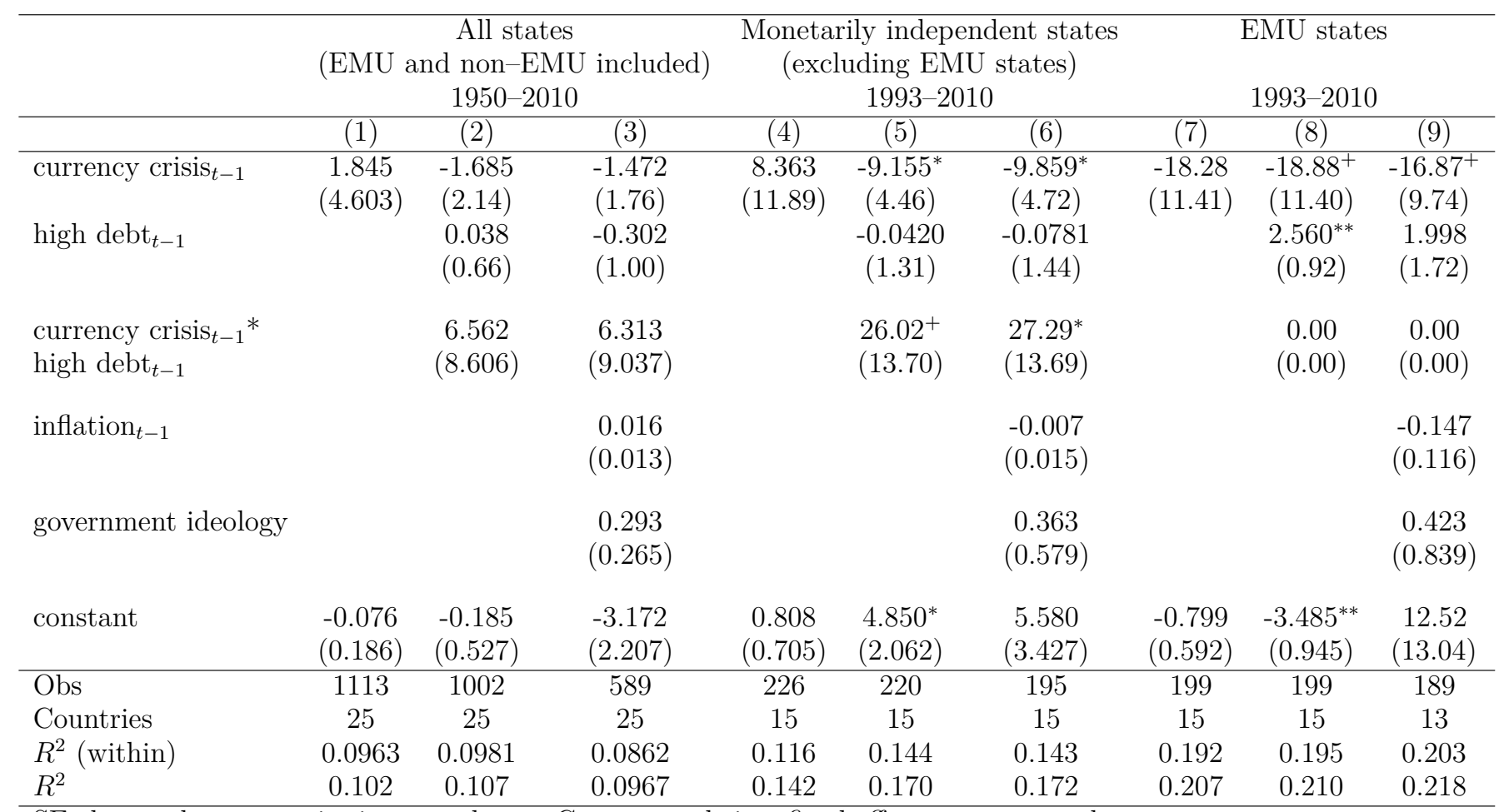

SE clustered on countries in parentheses. Country and time fixed effects not reported.

${ }^{+} p<0.1,{ }^{*} p<0.05,{ }^{* *} p<0.01$ 
Table A.11: Financial Crises and Change in Oversight Institutions: Currency Crises

\begin{tabular}{|c|c|c|c|c|c|c|c|c|c|}
\hline & \multicolumn{3}{|c|}{$\begin{array}{c}\text { All states } \\
\text { (EMU and non-EMU included) } \\
1950-2010\end{array}$} & \multicolumn{3}{|c|}{$\begin{array}{l}\text { Monetarily independent states } \\
\text { (excluding EMU states) } \\
\text { 1993-2010 }\end{array}$} & \multicolumn{3}{|c|}{$\begin{array}{l}\text { EMU states } \\
1993-2010\end{array}$} \\
\hline & (1) & $(2)$ & (3) & $(4)$ & (5) & (6) & (7) & $(8)$ & (9) \\
\hline 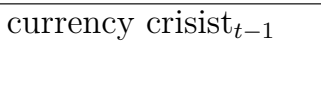 & $\begin{array}{c}0.331 \\
(0.220)\end{array}$ & $\begin{array}{l}0.107^{+} \\
(0.059)\end{array}$ & $\begin{array}{l}-1.472 \\
(1.76)\end{array}$ & $\begin{array}{l}0.274 \\
(0.28)\end{array}$ & $\begin{array}{c}0.269 \\
(0.258)\end{array}$ & $\begin{array}{l}0.355^{+} \\
(0.198)\end{array}$ & $\begin{array}{l}1.636^{* *} \\
(0.072)\end{array}$ & $\begin{array}{l}1.640^{* *} \\
(0.073)\end{array}$ & $\begin{array}{l}1.637^{* *} \\
(0.076)\end{array}$ \\
\hline high debt $_{t-1}$ & & $\begin{array}{c}0.012 \\
(0.023)\end{array}$ & $\begin{array}{l}-0.302 \\
(1.00)\end{array}$ & & $\begin{array}{l}-0.025 \\
(0.086)\end{array}$ & $\begin{array}{c}0.028 \\
(0.081)\end{array}$ & & $\begin{array}{l}-0.019 \\
(0.019)\end{array}$ & $\begin{array}{l}-0.019 \\
(0.021)\end{array}$ \\
\hline $\begin{array}{l}{\text { currency } \text { crisist }_{t-1}}^{*} \\
\text { high debt }_{t-1}\end{array}$ & & $\begin{array}{c}0.355 \\
(0.248)\end{array}$ & $\begin{array}{l}6.313 \\
(9.03)\end{array}$ & & $\begin{array}{c}0.00 \\
(0.00)\end{array}$ & $\begin{array}{c}0.00 \\
(0.00)\end{array}$ & & $\begin{array}{c}0.00 \\
(0.00)\end{array}$ & $\begin{array}{c}0.00 \\
(0.00)\end{array}$ \\
\hline inflation $_{t-1}$ & & $\begin{array}{l}0.002^{*} \\
(0.001)\end{array}$ & $\begin{array}{c}0.016 \\
(0.013)\end{array}$ & & & $\begin{array}{c}0.002^{*} \\
(0.001)\end{array}$ & & & $\begin{array}{c}0.001 \\
(0.001)\end{array}$ \\
\hline government ideology & & $\begin{array}{l}-0.003 \\
(0.003)\end{array}$ & $\begin{array}{c}0.293 \\
(0.265)\end{array}$ & & & $\begin{array}{c}0.004 \\
(0.008)\end{array}$ & & & $\begin{array}{l}-0.001 \\
(0.004)\end{array}$ \\
\hline constant & $\begin{array}{l}-0.005 \\
(0.008)\end{array}$ & $\begin{array}{r}-0.187^{+} \\
(0.097)\end{array}$ & $\begin{array}{l}-3.172 \\
(2.207)\end{array}$ & $\begin{array}{l}0.025 \\
(0.024)\end{array}$ & $\begin{array}{l}-0.008 \\
(0.082)\end{array}$ & $\begin{array}{c}0.00 \\
(0.00)\end{array}$ & $\begin{array}{l}0.036^{* *} \\
(0.006)\end{array}$ & $\begin{array}{l}0.057^{* *} \\
(0.018)\end{array}$ & $\begin{array}{c}0.006 \\
(0.120)\end{array}$ \\
\hline Obs & 710 & 512 & 589 & 191 & 188 & 168 & 199 & 199 & 189 \\
\hline Countries & 24 & 24 & 25 & 14 & 14 & 14 & 15 & 15 & 13 \\
\hline$R^{2}$ (within) & 0.218 & 0.253 & 0.0862 & 0.406 & 0.441 & 0.459 & 0.591 & 0.591 & 0.596 \\
\hline$R^{2}$ & 0.242 & 0.281 & 0.0967 & 0.420 & 0.453 & 0.475 & 0.602 & 0.603 & 0.606 \\
\hline
\end{tabular}

SE clustered on countries in parentheses. Country and time fixed effects not reported.

${ }^{+} p<0.1,{ }^{*} p<0.05,{ }^{* *} p<0.01$ 


\section{Supplementary Material}

\section{Crises, CBI and Democracy in Global Cross-National Perspective}

Our theory is tailored to the supranational entity that is the European Union. As such, we do not expect our theories to guide explanations for monetary policies and delegation mechanisms across all countries. Nonetheless, we believe the tension between economic independence and democracy is not as stark as it is thought to be also in polities outside of the EU. To substantiate and validate the theory, we then ran further analyses based on the global dataset of 182 countries identified by Laeven and Valencia (2008, 2012), who measure debt, banking and currency crises from 1950 until $2010 .{ }^{38}$

We used the same sources to construct the change of CBI variable for the global sample (Bodea and Hicks 2014; Sadeh). Of course, since we do not possess refined information on political delegation, we rely on the coarser measure of democracy as measured by the Polity IV score. We construct a binary variable that takes the value of 1 if the score changes positively by three or more points from one year to another. ${ }^{39}$ As per debt, we generate more variation in the Abbas et al (2011) measure by cumulating countries' five-year debt levels, therefore constructing an 'aggregate' debt level variable. The baseline estimation strategies are two-way fixed effect linear models with country-clustered standard errors for the CBI change outcome, and a two-way fixed effect probit models for the polity change (democratization) outcome, but we also explore other specifications (e.g. GEE models) that confirm our general inferences.

Our global findings shed important light on the mechanism that we identified for the EU. We find that banking crises increase the power of economic agents like central banks (Figure B.1). Contrarily to the European findings, however, we find that high debt is also conducive to power delegation to these technocratic actors. We also find that two interacting symptoms of financial stress have a positive effect. No country with a cumulated debt exceeding 100 percent of GDP (i.e. 500 percent of the five-year accumulated debt to GDP) has historically decreased the autonomy of the national central bank. By contrast, Bulgaria (1998) or Chile (1990) - like Italy in 1994 - increased the independence of their national banks in sovereign debt crises of a similar magnitude. Figure B.2 shows that the relationship between debt and CBI is rather involved. More specifically, the positive relationship between the cumulated debt indicator and the central bank independence measure only holds for the countries which are in a strong, but not yet extreme sovereign debt crisis where the cumulated debt of five years approaches or surpasses 1000 percent of the five-year cumulated GDP. A similar relationship holds, as subfigure $b$ reveals, for the interaction between debt and banking crisis.

The analysis of democratization also shows some important findings. In our dataset, we identify 161 instances of democratization, such as Argentina 1973, Peru 1956, beside the European cases already discussed. ${ }^{40}$ Here we study the effect of currency crises as well, as we are agnostic about the differences that banking and currency crises should have across the heterogenous groups of independent states in the global sample. We find that

\footnotetext{
${ }^{38}$ Our outcome variables for the global datasets extend to 2010, but note that many of our covariates are only available up to 2007.

${ }^{39}$ We co-validated our findings with the Bormann and Golder index of democracy (2013). Also, the results are just marginally weaker if we consider a change by the threshold of four points.

${ }^{40}$ Furthermore, we observe 98 autocratizations (e.g. Belarus 1995, Haiti 1991, Congo 1997).
} 
the predicted coefficients of lagged crises tend to be higher than 1 (Figure B.3). ${ }^{41}$ The statistical significance indicates that, although weakly, financial crises have usually had a positive impact on the chance of democratization. Our results additionally indicate that high sovereign debt has a positive role to play in democratization processes (Figure B.4). In the global sample, there is not a single case of a country that became more autocratic after experiencing five years with a significantly expansive fiscal policy $(>100$ percent yearly debt through GDP ratio). There are, however, several countries which underwent political liberalization under the same condition, e.g. Chile 1990, Guyana 1992, Hungary, 1990, and Sierra Leone 1996.

\footnotetext{
${ }^{41}$ In separate autocratization regressions, we find that the results are generally null. Results are available upon request.
} 
Table B.1: Selected CBI changes and regime change in global sample

\begin{tabular}{|c|c|c|}
\hline & CBI loss $(<20)$ & CBI gain $(>51)$ \\
\hline & & Armenia 1998 \\
& Spain 1975 & Djibouti 1999 \\
Democratization & Spain 1976 & Greece 1974 \\
(Polity change $>+3)$ & Spain 1977 & Guatemala 1986 \\
& Spain 1978 & Mexico 1994 \\
& & Peru 1993 \\
& & Peru 2000 \\
\hline
\end{tabular}

Table B.2: Selected CBI changes and banking crises in the global sample

\begin{tabular}{|c|c|c|}
\hline & CBI loss $(<20)$ & CBI gain (> 51) \\
\hline \multirow{3}{*}{ Banking crisis } & Costa Rica 1996 & Armenia 1997 \\
& Finland 1994 & Estonia 1995 \\
& Georgia 1995 \\
\hline \multirow{3}{*}{ No banking crisis } & Austria 1972 & \\
& Egypt 1972 & \\
& France 1972 & Bosnia Hzg 1998 \\
& Portugal 2002 & France 1994 \\
& Singapore 2000 & \\
\hline
\end{tabular}


Table B.3: Selected historical banking crises by regime change

\begin{tabular}{|c|c|}
\hline Autocratization & Democratization \\
\hline Albania 1996 & Albania 1997 \\
Algeria 1992 & Argentina 1983 \\
Armenia 1995 & Armenia 1998 \\
Armenia 1996 & Bangladesh 1991 \\
Burundi 1996 & Congo 1992 \\
Belarus 1995 & DRC 1992 \\
Belarus 1996 & Croatia 1999 \\
Chad 1984 & Benin 1990 \\
Guinea Bissau 1998 & Indonesia 1999 \\
Zambia 1996 & Madagascar 1991 \\
& Jordan 1989 \\
& Mali 1991 \\
& Mexico 1994 \\
& Nepal 1990 \\
& Nicaragua 1990 \\
& Panama 1989 \\
& Philippines 1986 \\
& Romania 1990 \\
& Spain 1977 \\
& Spain 1978 \\
& Turkey 1983 \\
& Uruguay 1985 \\
\hline
\end{tabular}


Figure B.1: Impact of financial crises on change in CBI, global sample

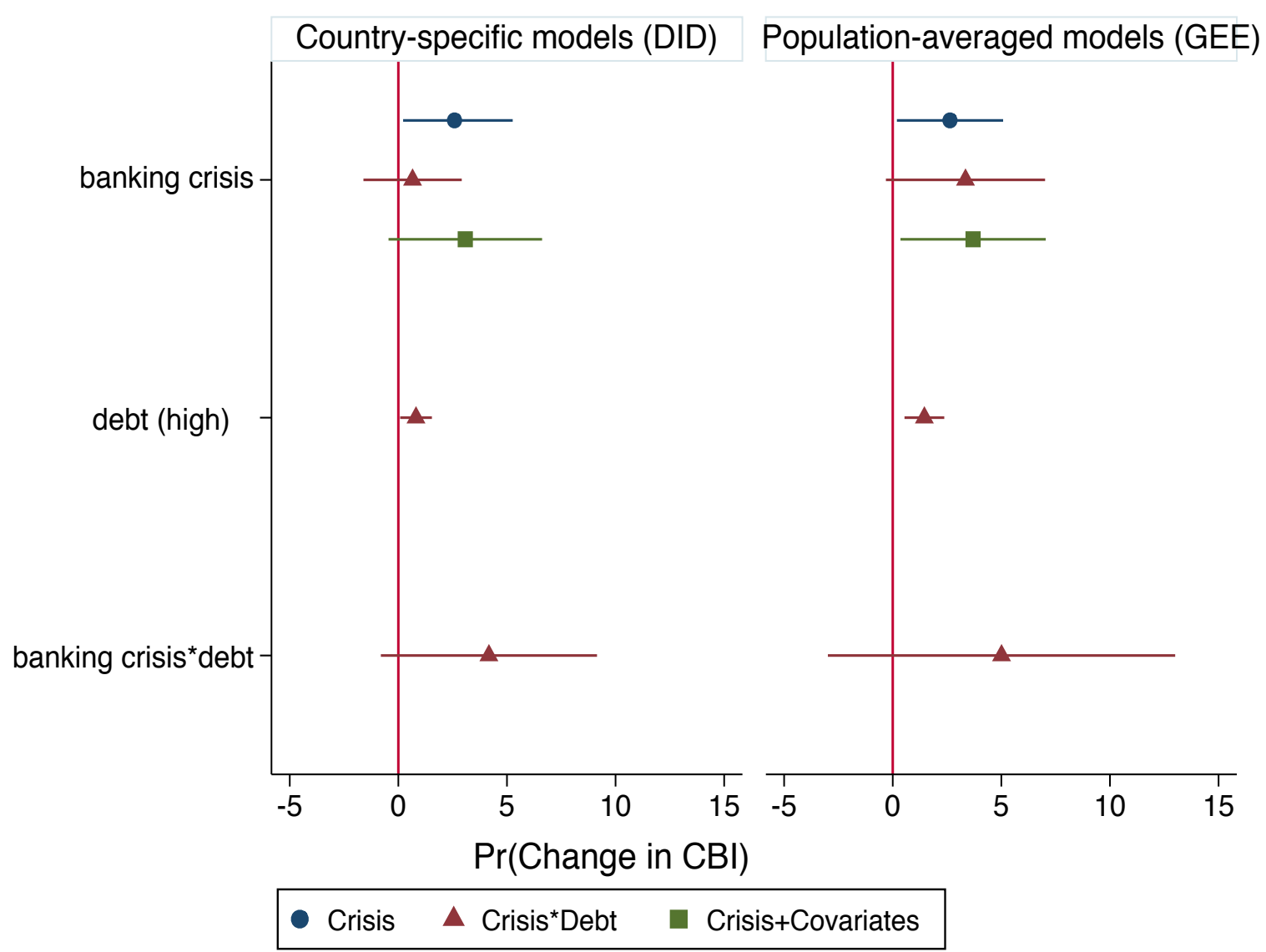

The plots show the linear coefficients of pooled OLS regressions of CBI changes on our main measures of financial stress. Each set of models presents, on the left side, the difference-in-differences models and, on the right side, the population-averaged models. Covariates are lagged inflation and government ideology. Line segments are 90 percent confidence intervals. 
Figure B.2: Marginal effects of crises on change in CBI, global sample

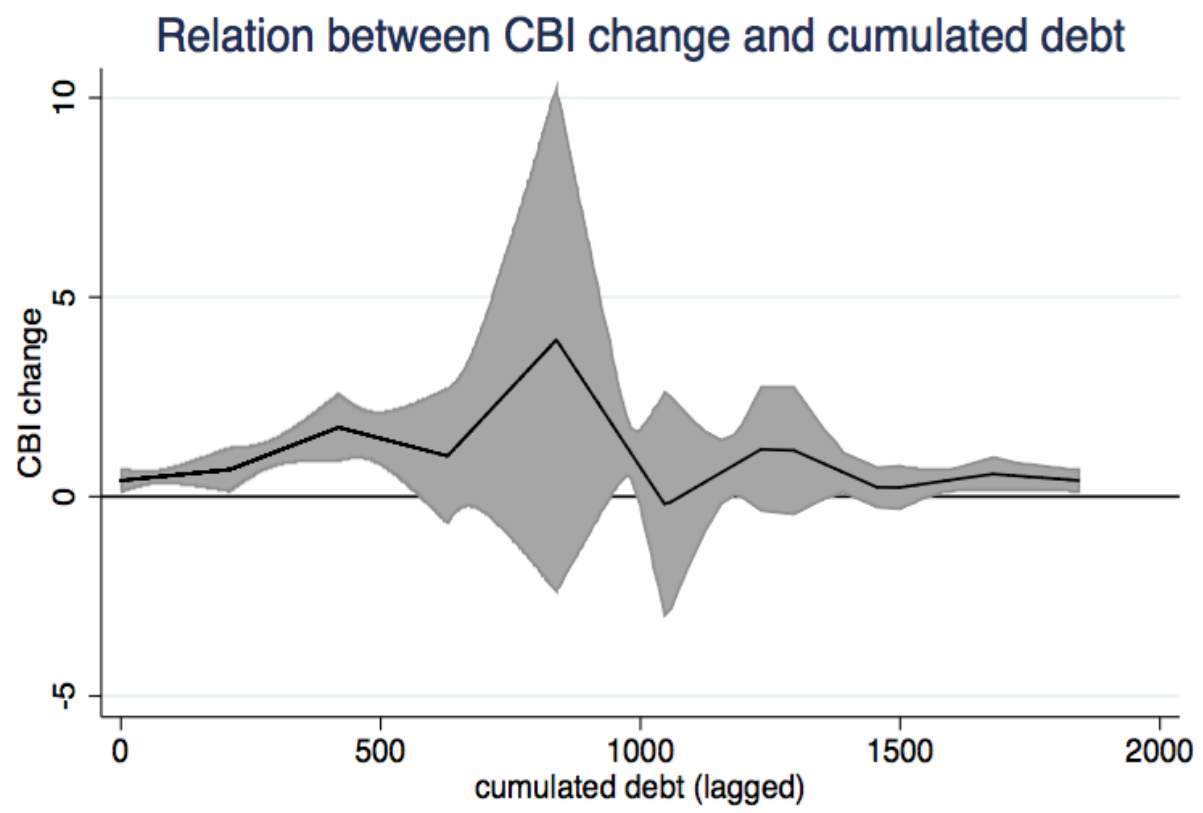

Marginal effects are simulated values constructed with linear spline at 20 different knots of the distribution of cumulated debt (5-year sum of debt to GDP ratio). 
Figure B.3: Correlational analysis of economic crises and democratization, global sample

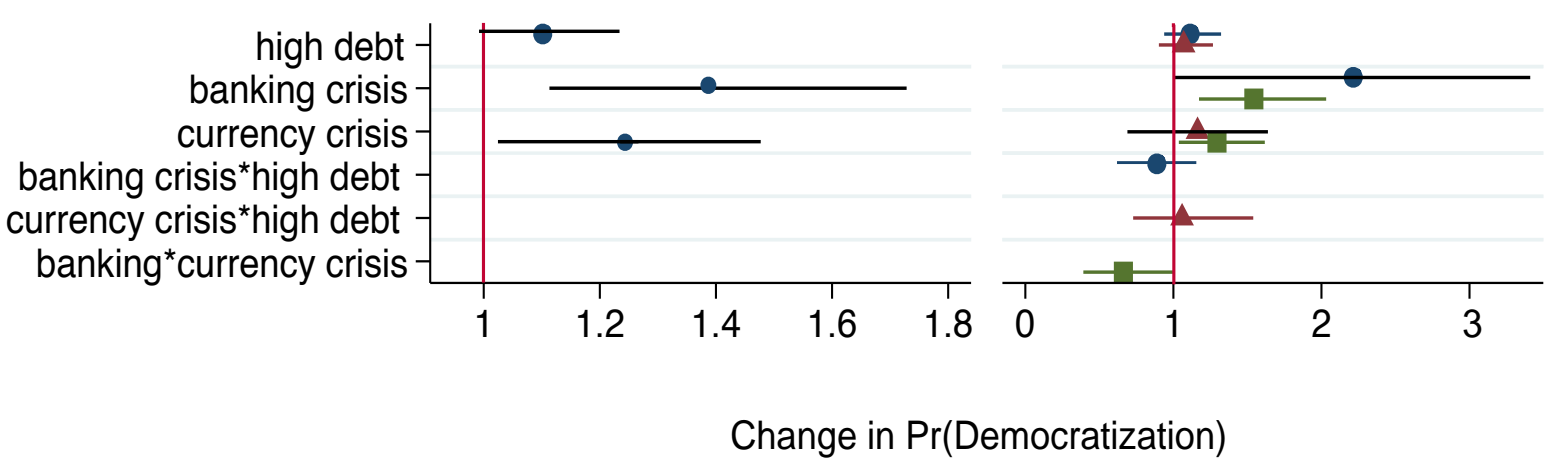

The plots show the exponentiated coefficients (odds ratios) of population-averaged probit regressions of polity score changes on different measures of financial stress. Each set of models presents, on the left side, the univariate models and, on the right side, the models with interaction effects. For the latter, coefficients plotted in the same shape represent the variables of each respective interaction model. Line segments are 95 percent confidence intervals 
Figure B.4: Joint effects of debt and banking crises on democratization, global sample

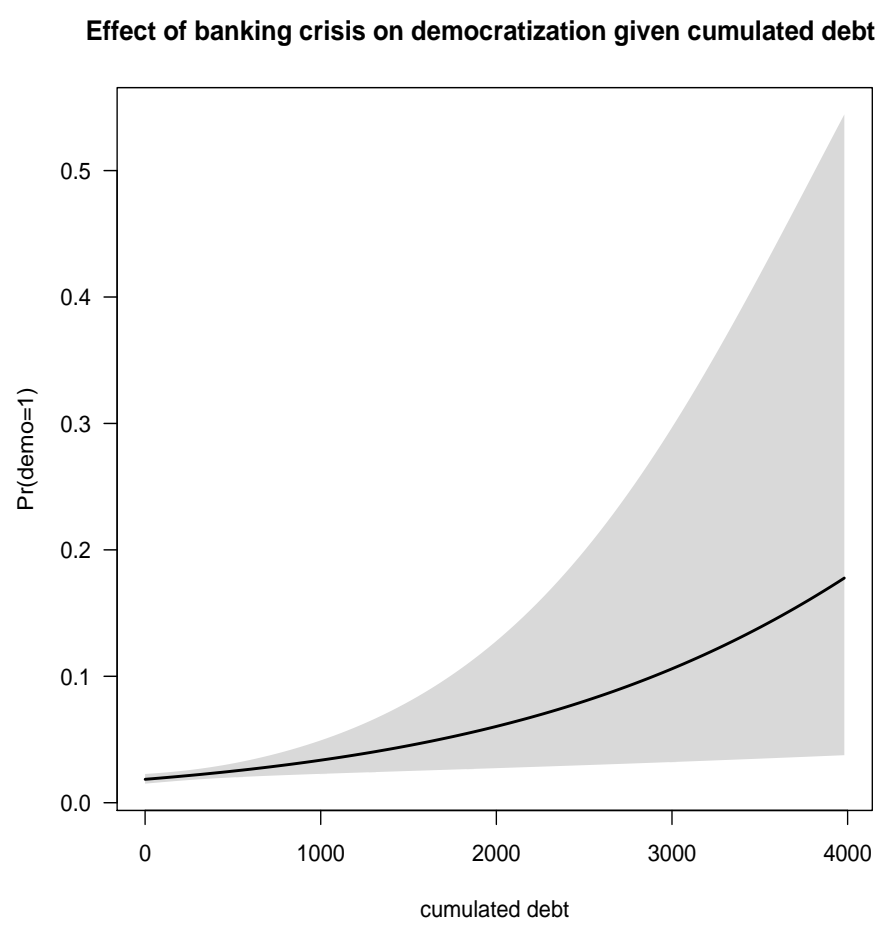

Plots are based on country-fixed effects probit models run on the global sample (Figure B.3). 